$1-1-1930$

\title{
The Effect of Feeding Different Amounts of Calcium and Phosphorus Upon the Growth and Development of Dairy Animals
}

H. O. Henderson

Charles Edward Weakley

Follow this and additional works at: https://researchrepository.wvu.edu/ wv_agricultural_and_forestry_experiment_station_bulletins

\section{Digital Commons Citation}

Henderson, H. O. and Weakley, Charles Edward, "The Effect of Feeding Different Amounts of Calcium and Phosphorus Upon the Growth and Development of Dairy Animals" (1930). West Virginia Agricultural and Forestry Experiment Station Bulletins. 231.

https://researchrepository.wvu.edu/wv_agricultural_and_forestry_experiment_station_bulletins/231 @ WVU. It has been accepted for inclusion in West Virginia Agricultural and Forestry Experiment Station Bulletins by an authorized administrator of The Research Repository @ WVU. For more information, please contact ian.harmon@mail.wvu.edu. 
West Virginia University Libraries

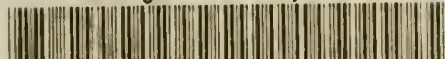

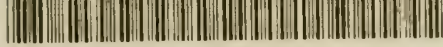

308021008961191 

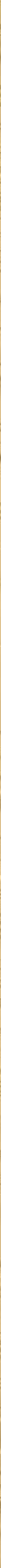
West Virginia University Library

This book is due on the date indicated below.

below.


Digitized by the Internet Archive in 2010 with funding from

Lyrasis Members and Sloan Foundation 


\section{The Effect of Feeding Different Amounts} of Calcium and Phosphorus upon the Growth and Development of Dairy Animals

by H. O. HENDERSON and C. E. WEAKLEY, JR. 


\section{AGRICULTURAL EXPERIMENT STATION STAFF}

JOHN R. TURNER, Ph. D., LL. D.............. President of the University

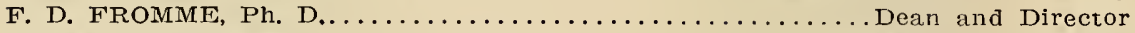

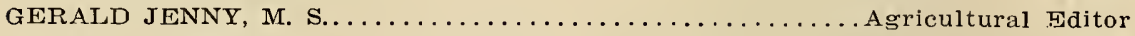

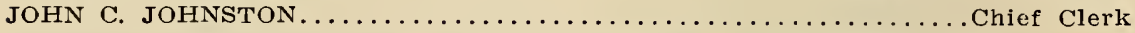

\section{AGRONOMY AND GENETICS}

R. J. Garber, Ph. D.

Agronomist and Geneticist

E. P. Deatrick, Ph. D. Associate Agronomist

W. H. Fierre, Ph. D. Associate Agronomist

T. C. McIlvaine, Ph. D.t Assistant Agronomist

D. R. Dodd, B. S.,t Assistant Agronomist

M. M. Hoover, M. S. Assistant Agronomist

H. K. Rowley, M. S. Agr. ** Seed Analyst

ANIMAL HUSBANDRY

E. A. Livesay, D. Sc.

Aninal IJusbandman

Chas. V. Wilson, M. S. Assistant Animal Husbandman

J. H. Longwell, M. A.

Assistant Animal Husbandinan

J. H. Rietz, D. V. M.

Associate Veterinarian

R. H. Tuckwiller, B. S. Agr.*

Assistant Animal Husbandman

R. S. Glasscock, M. S.**

Assistant in Veterinary Science

CHEMISTRY

R. B. Dustman, Ph. D.

Agricultural Chemist

Chas. E. Weakley, Jr., B. A. Assistant Chemist

L. P. Hansen, Ph. D.

T. B. Leith, M. S.**

Assistant Chemist

Assistant Chemist

Leland Shriver, B. S. Ch. E.

Assistant in Agricultural Chemistry

DAIRY HUSBANDRY

H. O. Henderson, Ph. D.

I. M. Thurston, Ph. D.

Dairy Husbandınan Assistant Dairy Husbandman

K. S. Morrow, M. S. Assistant Dairy Husbandman

L. F. Sutton, B. S. Agr. $\ddagger$ Assistant Dairy Husbandman

\section{ENTOMOLOGY}

L. M. Peairs, Ph. D.
W. E. Rumsey, R. S.**

State Entomologist

Edwin Gould, B. S. Agr.

Assistant in Entomology

\section{FARM ECONOMICS}

A. J. Dadisman, Ph. D.

F. D. Cornell, Jr., M. S.

Farm Economist

Assistant Farm Mechanician

W. W. Armentrout, M. S.

Assistant Farm Economist

R. O. Stelzer, B. S.

Assistant in Farm Economics

\section{HOME ECONOMICS}

Rachel H. Colwell, M. A.

Home Economist

Hazel C. Cameron, M. A.

Research Specialist in Nutrition

\section{HORTICULTURE}

H. E. Knowlton, Ph. D.

Horticulturist

K. C. Westover, M. S. Agr.

Assistant Horticulturist

F. W. Craig, M. S. Aor.***

Assistant Horticulturist

M. B. Hoftman. M. S. Assistant in Horticulture

E. N. McCubbin, M. A. Assistant in Horticulture

A. P. Dye, M. S. Agr. Assistant in Horticulture

\section{PIAANT PATHOLOGY}

C. R. Orton, Ph. D.

Anthony Bers, M. S.

Plant Pathologist Associate Plant Pathologist

L. H. Leonian, Ph. D. Associate Plant Pathologist

F. J. Schneiderhan, M. S. Associate Plant Pathologist

E. C. Sherwood, M. S. Assistant Plant Pathologist

\section{POULTRY HUSBANDRY}

Horace Atwood, M. S. Agr. Poultry Husbandman

T. B. Clark, B. S. Agr. Assistant in Poultry Hisbandry

Entomologist

*In cooperation with the U. S. Department of Agriculture, Washington, D. C. $\dagger$ In charge of the Lakin Sub-Station, Lakin, W. Va.

\pm Resigned, February, 1930.

* In cooperation with the State Department of Agriculture, Charleston, W. Va.

fIn charge of the Reymann Menorial Farms, Wardensville, Wr. Va. 


\section{The Effect of Feeding Different Amounts of Calcium and Phosphorus upon the Growth and Development of Dairy Animals *}

by H. O. HENDERSON and C. E. WEAKLEY, JR. $†$

$I^{1}$ T HAS long been known that calcium and phosphorus are necessary in the rations of farm animals if they are to grow and have normal development. It was generally supposed, however, that any ration which supplied sufficient protein, carbohydrates, and fat to meet the requirements of the growing animal would also supply sufficient amounts of these two minerals. For this reason very little consideration has been given to the optimum amount of calcium and phosphorus required for normal growth and development of the dairy heifer.

In recent years much experimental work in mineral metabolism has emphasized the importance of calcium and phosphorus in the ration and has shown that these elements sometimes may not be present in sufficient amounts for normal growth and development. Within the last decade a dietary factor has been discovered which aids in the assimilation of calcium and phosphorus. 'The ultra-violet rays, when animals are exposed to them, also have the power to help with this assimilation. Most of such studies have been made with small laboratory animals or with such domestic animals as the chicken, the pig, or the dairy cow, but very little has been done with the growing dairy animal.

It has also been shown recently that in many sections of the country the soil is deficient in calcium or, more especially, in phosphorus, to the extent that the forage grown on it will not support normal growth and development in dairy heifers. This has led to the belief, fully substantiated, that some of the roughage grown in various parts of the country may be extremely low in one or both of these elements.

There has been a tendency also in late years toward the feeding of more and more by-products of milling and other industries. Such feeds are also quite low in one or both of these elements, with a correspondingly greater chance that a ration may be deficient in these minerals.

* Submitted for publication March, 1929 .
TThe material in this bulletin was presented by the senior author in partial fulfilmment of the requirements for the degree of doctor of philosoping at the University of Minnesota. He is indebted to Dr. C. H. Eckles and Dr. L. S. Palmer of the Minnesota Agriculturai Experiment Station for help in outlining the inrestigation described and for many helpful suggestions received during the entire period of investigation. 
With these points in mind it seemed important that a study of the requirements of the growing dairy heifer for calcium and phosphorus be made. The investigations herein reported were made to determine the effects upon the growing dairy heifer of feeding rations containing various amounts of calcium and phosphorus. The studiy was not intended to determine the exact requirements for calcium and phosphorus because of the many other factors involved, but was made as a contribution toward that end. When we consider that more than 4,500,000 dairy calves must be raised each year in order to maintain the present supply of dairy cows, the importance of additional information in this direction is readily apparent.

\section{REVIEW OF LITERATURE}

The deposition of calcium and phosphorus in the animal body has been a field of study for many years. Among the earlier investigators who studied the effects of rations low in minerals upon animals were Chossat (1842), who worked with pigeons; Weiske (18\%2), and Weiske and Wildt (1873), who used goats and lambs; Forster (1873) who employed pigeons and later dogs; Voit (1880) who also used pigeons and dogs; and Aron and Sebauter (1908) who worked upon rabbits and dogs. These investigators demonstrated the necessity of minerals in the diet.

Later studies by Osborne and Mendel (1918) have shown that the rat will not develop unless given sufficient minerals in its diet. Sherman and Pappenheimer (1921) and McCollum and co-workers (1921) have shown that rickets in rats can be produced by feeding rations low in one or both of these minerals.

A trouble known as leg weakness in chickens also has been attributed to the lack of sufficient minerals in the ration and has been described by Hart, Halpin, and Steenbock (19.20) as a form of rickets which occurs when baby chicks are kept in confinement and when the chicks are from 4 to 8 weeks old.

Maynard, Goldberg, and Miller (1925), Bohstedt (1926) and coworkers (1927), and others have shown that when pigs are fed rations low in calcium, posterior paralysis results. This condition is due to a broken vertebra pressing upon the spinal cord. Somewhat similar results were obtained by Hart, McCollum, and Fuller (1909) when pigs were fed rations low in phosphorus.

The effects of feeding rations low in calcium and phosphorus to cattle also have been noted within recent years. The occurrence of abnormal conditions in cattle due to a mineral deficiency has been reported in various parts of the United States. In such sections the soil is so deficient in calcium, and more often in phosphorus, that the forage grown upon it is low in its content of these two minerals. In such sections the cattle very often are stunted, showing extreme emaciation, stiffness in the hind quarters and also at times in the front quarters, swollen joints, harshness of coats, dull eyes, unthrifty condition, and perverted appetite. Such areas are known as mineral deficiency areas. Studies of this subject have been made by Welch 
(1924) in Montana, by Schmidt (1921) in Texas, by Eckles, Recker, and Palmer (1926) in Minnesota, and by Hart and co-workers (19.2\%) in Wisconsin. The trouble has also been reported in West Virginia and Alabama by Halverson and Nixon (1921), in Florida by Bitting (189.1), in Pennsylvania by Pearson (1898), and in various other states.

Similar areas have been reported in other countrics. Von Gohren (1861) and Nessler (18\%3) reported such trouble in Germany, Aston (1905) in New Zealand, Murphy (1917) in Victoria, Theiler (1920) and associates (1921) in Suth Africa, Tuff (1924) in Norway, and Marcq (1925) in the Belgian Congo. This condition is no doubt much more widespread than these scattered reports indicate.

Very little experimental work has been reported concerning the effects of rations low in calcium and phosphorus upon growing dairy animals. Eckles and Swett (1918) found that a dairy heifer when ted a ration low in calcium made normal growth up to eighteen months of age, but that she then became stiff in her joints and could get ip only with the greatest difinculty. Rose (1912) found that dairy cows receiving a low phosphorus ration for four weeks became stiff in the joints and decreased in milk flow. Salmon and Eaton (1925) ivere unable to increase the growth of heifers by the addition of bonemeal to the ration.

Forbes and co-workers (1922) after extensive mineral balance experiments with dairy cows in milk flow $(1916,1917,1918,1922 a)$ concluded that the calcium metabolism of the milk cow while on winter feeds is characterized by rapid loss from the body during the early part of lactation, changing to retention late in lactation, and by continted retention during the dry period, with most rapid storage at the end of the period of gestation. Hart and associates (1921, 1922, 1923,1923 a) have found that green plant tissue contains the factor which assists in assimilation of minerals by the dairy cow. 'The same authors (1.924) also found that the ultra-violet rays have a beneficial influence upon the assimilation of calcium and phosphorus by a milking goat.

\section{METHODS EMPLOYED IN THE EXPERIMENT}

The object of the experiment was to determine the effect upon growing dairy heifers of feeding rations which contained difierent amounts of calcium and phosphorus.

In order to make such a study 32 grade Holstein heifer calves were divided into 4 groups of 8 calves each. Each group was fec. a ration as sinilar to the other rations in its digestıble crude protein and total nutrient content as it was practical to obtain. All were red according to the Morrison Feeding Standard for dairy heifers. The chief difference between the rations fed was in the calcium and phosphorus content.

Group I, the check group, during the trial was fed, as far as could be ascertained before the beginning of the experiment, a normal ration. This ration was selected as typical of those fed under practi- 
cal farm conditions. Since this ration contained a legume hay as onehalf of the roughage and a typical grain mixture which has been fed widely without apparent bad results, it was assumed that its calcium and phosphorus content was sufficient.

Group II was fed a ration very much lower in its calcium content but otherwise similar to that of Group I in its nutritive value. Group II was designated as the low-calcium group.

Group III, designated as the low-phosphorus group, was fed a ration similar in its nutritive value to that fed to Group I with the exception that it was much lower in its phosphorus content.

Group IV, designated as the low-calcium-low-phosphorus group, was fed a ration low in both calcium and phosphorus as compared to the ration fed to Group I, but otherwise similar in its nutritive value.

The animals were handled and cared for in the same manner throughout the experiment, in order that, as far as could be ascertained, the rations consumed would constitute the only difference between the 4 groups. There was, of course, some difference in the individuality of the calves, but this probably was not pronounced, since the groups were quite uniform at the beginning of the experiment.

In order to study the difference between the rations. the heifers were weighed and the height at their withers was measured at weekly intervals so that the growth of the animals could be ascertaineci. The calves also were watched daily for all atmormalities, and notes were taken as to their general appearance, health, period of oestrum, unnatural cravings, or any other tendencies.

Analyses were made also of the blood for calcium and inorganic phosphorus at three-month intervals in order to ascertain the effects of the ration upon the calcium and inorganic phosphorus content of the blood.

To ascertain the effects upon the internal organs and upon the bones of the animals, two animals from each group were slaughtered at the end of 8 months, two at the end of 13 months, two at the end of 19 months, and two at the end of 25 months. At the time of slaughter the internal appearance of the animals was noted, and weights were taken of the different internal organs. Samples of the long bones also were obtained for analysis and for determination of breaking strength.

Throughout the experiment Group I was considered as normal, and the other groups were compared to it.

\section{DESCRIPTION OF ANIMALS USED}

Thirty-two grade Holstein calves from 2 to 4 weeks in age were obtained from northern Pennsylvania, arriving in the coldest part of the winter. Most of them took sick and several died. Replacements in most cases from other shipments from the same source were made as soon as possible. Many of the calves, however, were slow to recover, and it was necessary to feed them milk much longer than had been planned. No knowledge of the ancestry of the animals was at hand. They were well marked, only two of them showing any Jersey 
characteristics. Since all cane from the same locality it may be assumed that they probably had somewhat the same general ancestry. They were under the normal size as given by Eckles (1920) in weight but not in height at withers.

The calves were divided into 4 groups as nearly as possible the same as to age, weight, and height at withers. In certain groups there were more replacements than in others, and hence the difference in size became somewhat greater; but in spite of such replacements the 4 groups were fairly uniform at the beginning of the experment. Table 1 gives the age, the time started on experiment, and the initial weight and height at withers for the various calves.

\section{Housing and Care of the Animals}

The animals were housed in a well-lighted and ventilated expcrimental barn. Each animal was kept in an individual pen so that it TABLE 1.-Date of Birth, Date of Starting on Experiment, Weight, and Iieight of Animals Used in the Experiment

\begin{tabular}{|c|c|c|c|c|}
\hline $\begin{array}{l}\text { Number } \\
\text { of Caif }\end{array}$ & $\begin{array}{l}\text { Date } \\
\text { Born }\end{array}$ & $\begin{array}{l}\text { T)ate Started on } \\
\text { Fxperiment* }\end{array}$ & Weight & $\begin{array}{c}\text { Height at } \\
\text { Withers }\end{array}$ \\
\hline \multicolumn{5}{|c|}{ GROUP I. NORMAL GROUP } \\
\hline $\begin{array}{l}\mathrm{E}-1 \\
\mathrm{E}-2 \\
\mathrm{E}-3 \\
\mathrm{E}-4 \\
\mathrm{E}-5 \\
\mathrm{E}-6 \\
\mathrm{E}-7 \\
\mathrm{E}-8\end{array}$ & $\begin{array}{l}1-24-26 \\
1-28-26 \\
2-3-26 \\
2-1-26 \\
1-28-26 \\
2-2-26 \\
2-3-26 \\
2-2-26\end{array}$ & $\begin{array}{l}2-22-26 \\
2-22-26 \\
2-22-26 \\
2-22-26 \\
2-22-26 \\
2-22-26 \\
2-22-26 \\
2-22-26\end{array}$ & $\begin{array}{c}\text { (pounas) } \\
100 \\
98 \\
87 \\
85 \\
79 \\
75 \\
69 \\
64\end{array}$ & $\begin{array}{l}(\mathrm{cms} .) \\
75.5 \\
73.3 \\
73.5 \\
74.0 \\
73.4 \\
71.6 \\
68.5 \\
69.0\end{array}$ \\
\hline Average & & & 82.1 & $\pi 2.3$ \\
\hline \multicolumn{5}{|c|}{ GROUP II. LOWV-CALCIUM GROUP } \\
\hline $\begin{array}{l}\mathrm{E}-9 \\
\mathrm{E}-10 \\
\mathrm{E}-11 \\
\mathrm{E}-12 \\
\mathrm{E}-13 \\
\mathrm{E}-14 \\
\mathrm{E}-15 \\
\mathrm{E}-16\end{array}$ & $\begin{array}{l}1-25-26 \\
4-10-26 \\
2-5-26 \\
2-5-26 \\
2-2-26 \\
2-4-26 \\
3-15-26 \\
2-8-26\end{array}$ & $\begin{array}{l}2-22-26 \\
4-20-26 \\
2-22-26 \\
2-22-26 \\
2-22-26 \\
2-22-26 \\
4-1-26 \\
2-22-26\end{array}$ & $\begin{array}{r}100 \\
80 \\
87 \\
85 \\
76 \\
75 \\
79 \\
67\end{array}$ & $\begin{array}{l}78.7 \\
71.0 \\
72.5 \\
72.8 \\
70.3 \\
71.6 \\
68.5 \\
74.4\end{array}$ \\
\hline Average & & & 81.1 & 72.3 \\
\hline \multicolumn{5}{|c|}{ GROUP III. IOTV-PHOSPHORUS GROUP } \\
\hline $\begin{array}{l}\mathrm{E}-17 \\
\mathrm{E}-18 \\
\mathrm{E}-19 \\
\mathrm{E}-20 \\
\mathrm{E}-21 \\
\mathrm{E}-22 \\
\mathrm{E}-23 \\
\mathrm{E}-24\end{array}$ & $\begin{array}{l}1-23-26 \\
2-6-26 \\
1-27-26 \\
1-31-26 \\
1-28-26 \\
2-4-26 \\
2-1-26 \\
3-15-26\end{array}$ & $\begin{array}{r}2-22-26 \\
2-22-26 \\
2-22-26 \\
2-22-26 \\
2-22-26 \\
2-22-26 \\
2-22-26 \\
4-1-26\end{array}$ & $\begin{array}{r}109 \\
96 \\
90 \\
82 \\
81 \\
74 \\
70 \\
82 \\
\end{array}$ & $\begin{array}{l}75.5 \\
75.0 \\
72.9 \\
74.2 \\
75.0 \\
70.3 \\
72.3 \\
72.0\end{array}$ \\
\hline Average & & & $85 . \overline{5}$ & 73.4 \\
\hline \multicolumn{5}{|c|}{ GROUP IV. LOW-CALCIUM-LOW-PHOSPHORUS GROUP } \\
\hline $\begin{array}{l}\mathrm{E}-25 \\
\mathrm{E}-26 \\
\mathrm{E}-27 \\
\mathrm{E}-28 \\
\mathrm{E}-29 \\
\mathrm{E}-30 \\
\mathrm{E}-31 \\
\mathrm{E}-32\end{array}$ & $\begin{array}{l}1-23-26 \\
2-24-26 \\
2-5-26 \\
1-30-26 \\
1-31-26 \\
4-10-26 \\
2-1-26 \\
3-15-26\end{array}$ & $\begin{array}{l}2-22-26 \\
3-1-26 \\
2-22-26 \\
2-22-26 \\
2-22-26 \\
4-15-26 \\
2-22-26 \\
4-1-26 \\
\end{array}$ & $\begin{array}{r}109 \\
110 \\
90 \\
84 \\
80 \\
90 \\
69 \\
89 \\
\end{array}$ & $\begin{array}{l}80.5 \\
74.0 \\
73.9 \\
71.1 \\
71.3 \\
73.0 \\
71.5 \\
75.0\end{array}$ \\
\hline Average & & & 90.1 & 73.8 \\
\hline
\end{tabular}

*The calves were put on the various rations outlined at about four months of age. 
could be fed separately. The pens were about $3 \mathrm{r} / 2$ by 4 feet in size. When the calves were 13 months old, after one-half their number had been slaughtered the pens were increased in size to about 5 by 6 feer. The animals remained in these pens all the time except once a veek, when they were removed to be weighed and measured. This was done in the same barn. They were removed from the barn but once every six months, when they were being photographed.

Although the barn had an abundance of light, the ultra-violet rays were not a factor to be considered, since the windows were kept closed. Hess and associates (19.22) have shown that common window glass will allow no wave lengths shorter than 334 millimicrons to pass through and so will filter out all of the light that is beneficial to calcium and phosphorus assimilation. Gullickson and Eckles (192\%), however, have found that dairy heifers can be grown satisfacturily away from the light even on rations not very high in calcium.

Exercise. The animals were given no exercise except what they were able to obtain in their pens and when they were weighed cach week. It was noted that many of them played a great deal in their pens, thus getting considerable exercise.

Bedding. The pens were bedded with shavings so that no nutrients were obtained from that source.

Weighing and Measuring. Weight of the animals and measurements at the height of the withers were taken at weekly intervals. These weights and measurements were averaged monthly.

Breeding. Since it was the object to study the effects of the rations on growing heifers, none of the animals was bred, in orcler that the factor of gestation might not enter into the problem. The times of oestrum, however, were observed in order to determine tine effect of the rations upon the time of the first signs of oestrunı and the regularity thereafter.

Salting. Once a week each heifer was given all the salt desired The salt was carefully weighed and placed before each animal and left there for about one hour, when it was removed and again weighed. In this way the amount consumed was ascertained.

The amount consumed varied from month to month, but the heifers on the restricted ration did not appear to crave the salt and did not consume any more than did those fed the normal ration. It was planned to restrict all calves to the same amount of salt as was consumed by the ones on the normal ration, but since the other calves did not seem to crave the salt, restriction was not found necessary.

Water. Water was given twice a day in buckets. Three times per month-on the fifth, fifteenth, and twenty-fifth days of the mointh -weights were taken of the amount consumed and used as the average daily consumption of water. There was considerable variation in the consumption of water by individual animals. Some individuals would average as much as 90 pounds per day for certain montis, while others would average as low as 20 pounds for the same month. Some were consistently heavy drinkers while others were just as consistently light drinkers. No apparent difference could be noted, 
however, between heavy and light drinkers. Neither could it be noted that any one group had a larger number of heavy drinkers than any other group.

When the average daily consumption of water per animal in each group was considered, very little difference could be noted in the amount consumed. Group II, the low-calcum group, consuned on the average about $2 \frac{1}{2}$ pounds more per day than the normal-fed group, and Group IV, the low-calcium-low-phosphorus group, consumed a little over one-half pound more than did the calves receivings the normal ration. Group III, the low-phosphorus group, on the other hand, consumed almost a pound less per day than the normalfed group.

TABLE 2.-Avcrege Composition of Fecis Used

\begin{tabular}{|c|c|c|c|c|c|c|}
\hline \multirow[b]{2}{*}{ Feed } & \multirow[b]{2}{*}{ Water } & \multirow[b]{2}{*}{ Ash } & \multirow{2}{*}{$\begin{array}{l}\text { Crude } \\
\text { Protein }\end{array}$} & \multicolumn{2}{|c|}{ Carbohydrates } & \multirow{2}{*}{$\begin{array}{l}\text { Ether } \\
\text { Extract }\end{array}$} \\
\hline & & & & (:r. Fiber & N.ISF. & \\
\hline 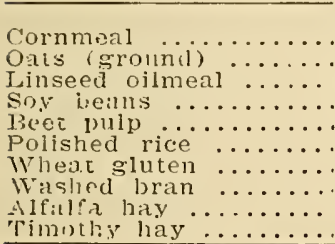 & $\begin{array}{c}\text { (vercent) } \\
9.96 \\
7.76 \\
5.07 \\
6.70 \\
7.64 \\
10.94 \\
7.74 \\
7.10 \\
5.7 .1 \\
5.33\end{array}$ & $\begin{array}{c}\text { (percent) } \\
1.54 \\
3.16 \\
5.15 \\
4.52 \\
3.21 \\
0.5 .67 \\
11.97 \\
1.50 \\
5.64 \\
4.70\end{array}$ & $\begin{array}{c}(\text { rrecut } \\
9.44 \\
10.87 \\
35.32 \\
39.70 \\
10.2 .7 \\
3.44 \\
80.22 \\
14.70 \\
11.54 \\
5.85\end{array}$ & 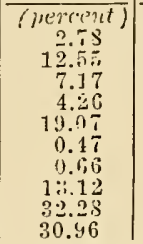 & $\begin{array}{c}(\text { percent) } \\
72.03 \\
61.52 \\
37.61 \\
24.84 \\
59.1 .2 \\
80.77 \\
9.94 \\
61.15 \\
43.98 \\
51.36\end{array}$ & $\begin{array}{c}\text { (percent) } \\
4.25 \\
3.54 \\
6.05 \\
19.58 \\
0.69 \\
0.39 \\
0.45 \\
2.13 \\
1.42 \\
1.80\end{array}$ \\
\hline
\end{tabular}

The water was analyzed for calcium and phosphorus and found to contain 2.96 parts of calcium per million parts of water and only a slight trace of phosphorus. The amount of these elements obtained from the water therefore was very small. The amount of calcium received per month through the water would be about 12 grams, which would amount to but 0.4 of a gram per day.

\section{Methods of Feeding}

Early Feeding. Since the calves were received in a weakened condition, many had to be fed whole milk and all had to be fed skimmill: for a much longer period than had been planned. It was impossible to make them consume the experimental ration for some time and so they were started on whole oats and later fed for a short period on a ration of equal parts of oats, corn, and linseed oilmeal. They were put on the experimental ration at 4 mionths of age, when they were growing normally. They were not weaned from skimmilk until they were five months of age; some individuals were fed skimmilk until they were six months old.

Analysis of Rations. Each animal was fed individually througinout the experiment. Necessary changes in the feeding were made at two-week intervals, and all refuse was carefully recorded daily. In this way a complete record was kept of all the feed consumed by each individual. A year's supply of feed was purchased at a time so that variations in the feeds would be kept at a minimum. These feeds were carefully sampled and analyzed each year. 'The results as given in Table 2 are the average analyses of the feeds for the two years of the experiment. 
Rations. The rations used throughout the experiment are given in Table 3.

The rations numbered from I to IV were fed during the first year of the experiment and were fed to Groups I to IV, respectively. They were calculated fo: a nornal 6-months old heifer and were fed so that each was receiving its requirements according to the Morrison standard.

When the heifers were a year old the rations were changed. This was made necessary because the requirements change slightly as the animals grow older, and, in the case of Rations III and IV, because analysis of the phospinorus content of the washed bran showed that only about one-third of the phosphorus was being removed by the method used in washing. Hart, McCollum, and Fuller (1909) had been able to wasl practically all of the phosphorus from bran by allowing whole bran to soak over night in warm water, when an acid fermentation resulted. The bran subsequently was thoroughly washed with water and dried. The bran washed in their work contained only 0.11 percent of phosphorus as compared to 1.51 percent for whole bran. The results in the present experiment showed that the bran washed in the manner described above contained on the average 0.94 percent of phosphorus, and as it was being fed for its supposedly low phosphorus content it was ai once omitted from the ration, and beet pulp was substituted.

TABLE 3.-Average Daity Fation Fed during Experiment

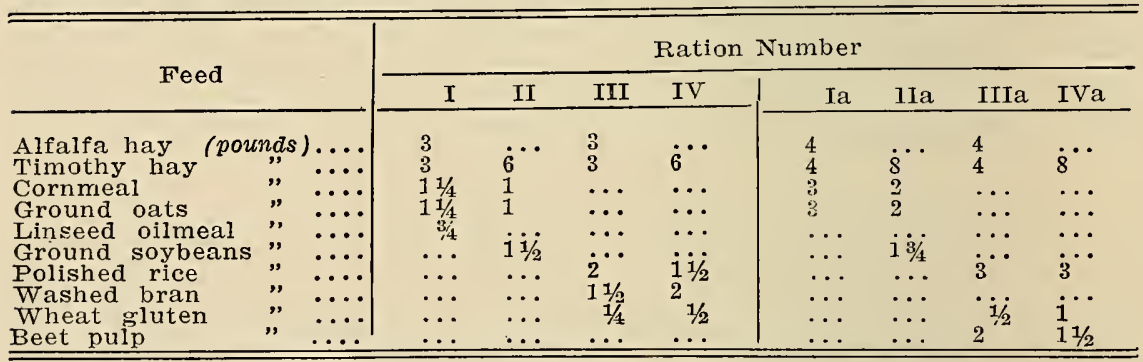

Rations Ia to IVa were fed cluring the second year of the experiment and were ferl to Groups I to IV respectively. They were calculated for normal 12-months old heifers and differed only from Rations I to IV in amounts, with the exception that linseed oilmeal was dropped out of Ration I to form Ration Ia, and beet pulp was substituted for washed bran in Rations III and IV to form Rations IIIa and IVa.

The average analyses as shown in Table 2 were converted to the digestible basis by the digestibility of American feed stuffs as given by Henry and Morrison (1923) whenever possible; otherwise the digestibility of some closely related feed was used. In this way the average amount of digestible protein and digestible nutrients consumed by each group was ascertained as is shown in Table 4. This table and many of those following are divided into periods, from the beginning of the experiment to 8 months, from 8 months to 13 
months, from 13 months to i9 months, and from 19 months to 25 months to correspond to the time of slaughtering the animals, as studies and comparisons can more easily be made in that manner.

Table 4 shows that, whereas there is considerable difference in the total amount of digestible crude protein and total digestible nutrients consumed per day, on the live weight basis there is very little difference. The normal group consumed slightly less digestible protein than did the other groups. There was very little difference between the amount of digestible nutrients consumed by the different groups per 100 pounds of live weight. This would indicate that, as far as nutritive value was concerned, the animals should make similar growth.

Calcium and 1'hosphorus Content of the Ration. The different feeds were analyzed for their ash and calcium and phosphorus content, with the results as shown in Table 5.

The feeds, as a general rule, analyzed just a little higher in calcium than has been found at other stations. This was especially true of the calcium content of the alialfa and timothy hay. Both contained more than twice as much calcium as was found by Forbes and coworkers (1913). Both also were lower in phosphorus than was found by Forbes. This was particularly true of the alfalfa hay, of second-

TABLe 4.--Average Daily Amount of Digestible Crude Protein and Total Digestible Nutrients Consumed by the Animals in Each Group, and Average Daily Amount

Consumed Per 100 Pounds of Live Weight of the Animals, by Periods

\begin{tabular}{|c|c|c|c|c|c|}
\hline $\begin{array}{c}\text { Period End- } \\
\text { ing when } \\
\text { Animals } \\
\text { Were at } \\
\text { Age of }\end{array}$ & 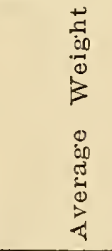 & 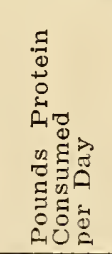 & 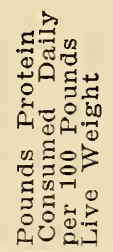 & 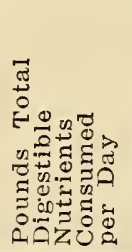 & 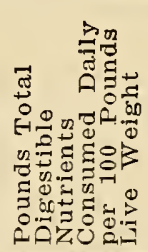 \\
\hline \multicolumn{6}{|c|}{ GROUP I. NORMAL GFIOUP } \\
\hline 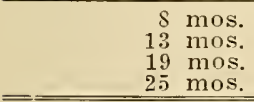 & $\begin{array}{l}196 \\
408 \\
646 \\
850 \\
\end{array}$ & $\begin{array}{l}0.67 \\
0.91 \\
0.91 \\
1.07 \\
\end{array}$ & $\begin{array}{l}0.34 \\
0.22 \\
0.14 \\
0.12 \\
\end{array}$ & $\begin{array}{r}3.86 \\
7.09 \\
9.74 \\
10.82 \\
\end{array}$ & $\begin{array}{l}1.97 \\
1.74 \\
1.51 \\
1.23 \\
\end{array}$ \\
\hline \multicolumn{6}{|c|}{ GROUP II. LOW-CALCILM GROUP } \\
\hline $\begin{aligned} & 8 \text { mos. } \\
& 13 \text { mos. } \\
& 19 \text { mos. } \\
& 25 \text { mos. } \\
&\end{aligned}$ & $\begin{array}{l}184 \\
381 \\
585 \\
750 \\
\end{array}$ & $\begin{array}{l}0.66 \\
1.11 \\
1.12 \\
1.26 \\
\end{array}$ & $\begin{array}{l}0.36 \\
0.29 \\
0.19 \\
0.17 \\
\end{array}$ & $\begin{array}{r}3.84 \\
7.61 \\
8.67 \\
10.09 \\
\end{array}$ & $\begin{array}{l}2.09 \\
2.00 \\
1.48 \\
1.34 \\
\end{array}$ \\
\hline \multicolumn{6}{|c|}{ GROUP III. LOW-PHOSPHORUS GROUP } \\
\hline $\begin{aligned} & 8 \text { mos. } \\
& 13 \text { mos. } \\
& 19 \text { mos. } \\
& 25 \text { mos. } \\
&\end{aligned}$ & $\begin{array}{l}192 \\
395 \\
617 \\
893 \\
\end{array}$ & $\begin{array}{l}0.63 \\
0.89 \\
1.09 \\
1.27 \\
\end{array}$ & $\begin{array}{l}0.33 \\
0.23 \\
0.1 \$ \\
0.14 \\
\end{array}$ & $\begin{array}{r}3.79 \\
6.90 \\
9.40 \\
10.43 \\
\end{array}$ & $\begin{array}{l}1.94 \\
1.75 \\
1.54 \\
1.25\end{array}$ \\
\hline \multicolumn{6}{|c|}{ Group IV. LOW-CALCIUN-JOW-PHOSPHORLS GROLP } \\
\hline $\begin{array}{r}8 \text { mos. } \\
13 \text { mos. } \\
19 \text { mos. } \\
25 \text { mos. }\end{array}$ & $\begin{array}{l}180 \\
366 \\
570 \\
731 \\
\end{array}$ & $\begin{array}{l}0.62 \\
0.93 \\
1.10 \\
1.28 \\
\end{array}$ & $\begin{array}{l}0.34 \\
0.25 \\
0.19 \\
0.17 \\
\end{array}$ & $\begin{array}{l}3.55 \\
6.50 \\
8.36 \\
9.37 \\
\end{array}$ & $\begin{array}{l}1.97 \\
1.86 \\
1.47 \\
1.28\end{array}$ \\
\hline
\end{tabular}


Table 5.-Average Amount of Ash, Calcium, and Phosphorus Found in 100 Pounds of Feed Used in Experiment

\begin{tabular}{|c|c|c|c|c|c|}
\hline Feed & $\begin{array}{l}\text { Pounds } \\
\text { Ash }\end{array}$ & Pounds & $\begin{array}{l}\text { Pounds } \\
\text { Calcium }\end{array}$ & $\begin{array}{l}\text { Pounds } \\
\mathrm{P}_{2} \mathrm{O}_{5}\end{array}$ & $\begin{array}{l}\text { Pounds } \\
\text { Phosphorus }\end{array}$ \\
\hline 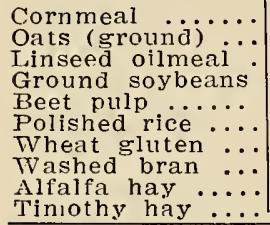 & $\begin{array}{l}1.34 \\
3.37 \\
5.72 \\
4.51 \\
3.56 \\
0.55 \\
1.01 \\
5.45 \\
8.53 \\
4.63\end{array}$ & $\begin{array}{l}0.038 \\
0.130 \\
0.530 \\
0.290 \\
1.100 \\
0.015 \\
0.100 \\
0.218 \\
3.300 \\
0.530\end{array}$ & $\begin{array}{l}0.027 \\
0.093 \\
0.379 \\
0.208 \\
0.788 \\
0.011 \\
0.072 \\
0.156 \\
2.369 \\
0.379\end{array}$ & $\begin{array}{l}0.69 \\
0.88 \\
1.90 \\
1.36 \\
0.20 \\
0.23 \\
0.73 \\
2.16 \\
0.35 \\
0.30\end{array}$ & $\begin{array}{l}0.301 \\
0.383 \\
0.828 \\
0.593 \\
0.097 \\
0.100 \\
0.315 \\
0.942 \\
0.159 \\
0.131\end{array}$ \\
\hline
\end{tabular}

cut alfalfa obtained from Michigan. Reed and Huffman (1928) have found that the alfalfa hay from parts of Michigan is quite high in calcium and low in phospliorus-a possible explanation of results. Tha fact that the analyses varied from the average has caused the rations to be higher in calcium and the normal phosphorus rations to be lower in phosphorus than was desired. The fact also that the phosphorus was not washed from the bran caused Rations III and IV to be much higher in phosphorus than was desired.

Table 6 shows the total amount of calcium and phosphorus in each of the rations used. It also shows the amount of each mineral per hundredweight of the animals and per 100 grams of the ration, and also the ratio between the phosphorus and calcium in each ration. The rations vary from 2.78 to 11.56 grams of calcium per 100 pounds of live weight and from 0.249 to 0.936 grams of calcium per 100 grams of the ration.

In phosphorus the rations vary from 1.43 to 3.86 grams per 100 pounds of live weight and from 0.131 to 0.298 grams per 100 grams of the ration. The ratio between the phosphorus and calcium varies from $1: 0.9$ to $1: 7.2$.

The average amount of calcium and phosphorus consumed by the calves in each group per day and the amount consumed per 100 pounds of the animal are shown in Table 7.

Table 7 shows tilat ciuring the first period all of the animals were fed rations containing considerably more of both calcium and phosphorus in relation to their weight than they received during later periods. This was due largely to the milk, which was fed in large amounts during the first pericd. Toward the latter part of the period, of course, the ration contained much less of these elements. In the ration of Groups I and III the calcium was supplied in fairly larga amounts at all times, due largely to the alfalfa hay fed. 'The calcium in the rations fed to Groups II and IV, however, was much restricted in relation to the weiglit of the animals.

During the first two periods the phosphorus was supplied fairly well in the rations of all 4 groups. It, however, was not extremeiy high in any of the rations. Inuring the last two periods the rations of Groups III and IV were quite low in phosphorus. The ration of 
Group I was quite low in its content of phosphorus during the last period, illustrating the fact that rations which are thought normal may sometimes be very close to the lower limit of the requirements of the animals.

\section{Discussion of the Rations Fed}

Amount of Phosphorns and. Calcium Fed. While there is no definite knowledge as to the correct amount of calcium and phosphorus to include in a ration for a dairy animal, several investigators have stated what they belicred to be the requirements for such animais, while others have calculated the amount retained by such animals.

Kellner (190\%) computerl the calcium and phosphorus retention of growing calves as 21 grams of $\mathrm{CaO}$ and 19 grams of $\mathrm{P}_{2} \mathrm{O}_{5}$ per day during the first year, which amounts to about 15 grams of calcium and 8.3 grams of phosplicrns per day. He states that the feed should contain from 40 to 60 grams of each per day.

Armsby (191\%) conputed from Lawes and Gilbert's analyses of the ash of the entire body of farm animals that during the first year, cattle gain a total of 5,609 grams of calcium and 2,972 grams of phosphorus. This is an average daily retention of 15.37 grams of calcium and 8.14 grams of phosphorus per animal. On a 100-pound basis, cattle during the first year require 3.2 grams of calcium and 1.7 grams of phosphorus daily in their bodies.

McCollum and co-workers (1922) have found that for rats a content of 0.641 grams of calcium per 100 grams of the ration is very near to the optimum concentration of this element. They (1922a) also found that the optimum amount of phosphorus for growing rats is not less than 0.4146 percent. It may be considerably higher.

If Kellner's and Armsby's figures, as given above, which check very closely with each other and which apply to the conditions in the present experiment, are considered, it can be seen by Tables 6 and 7 that Group I was being fed ample calcium and sufficient phosphorus, if there is a fairly high percentage of retention, throughout the entire experiment, although the amount of phosphorus during the latter part of the experiment was dangerously near the lower limits of the requirements. Group II was fed just about the amount of calcium

TABLe 6.-Total Anount of Calcium and of Phosnhorus, Amount of Each per Hundredweight of the Animal and per 100 Grams of the Tation, and Ratio between Phos?horus and Calcium in the Tarious Rations Indicated in Table 3

\begin{tabular}{|c|c|c|c|c|c|c|c|}
\hline $\begin{array}{l}\text { Ration } \\
\text { Number }\end{array}$ & $\begin{array}{l}\text { Grams } \\
\text { Calcium } \\
\text { in Daily } \\
\text { Ration }\end{array}$ & $\begin{array}{c}\text { Crams Ca } \\
\text { per cwt. } \\
\text { of } \\
\text { Animal }\end{array}$ & $\begin{array}{c}\text { Grams Ca } \\
\text { per } 100 \\
\text { Grams of } \\
\text { Ration }\end{array}$ & $\begin{array}{c}\text { Grams } \\
\text { Phos- } \\
\text { phorus } \\
\text { in Daily } \\
\text { Ration }\end{array}$ & $\begin{array}{c}\text { Grams P } \\
\text { per cwt. } \\
\text { of } \\
\text { Animal }\end{array}$ & $\begin{array}{l}\text { Grams P } \\
\text { per } 100 \\
\text { Grams of } \\
\text { Ration }\end{array}$ & $\begin{array}{c}\text { Ratio } \\
\text { between } \\
\mathrm{P} \text { and Ca }\end{array}$ \\
\hline 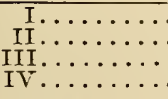 & $\begin{array}{l}39.32 \\
12.34 \\
40.47 \\
12.05\end{array}$ & $\begin{array}{r}11.23 \\
3.53 \\
11.56 \\
3.44\end{array}$ & $\begin{array}{l}0.936 \\
0.2 \$ 6 \\
0.914 \\
0.265\end{array}$ & $\begin{array}{l}10.53 \\
10.72 \\
11.54 \\
13.52\end{array}$ & $\begin{array}{l}3.01 \\
3.06 \\
3.30 \\
3.86\end{array}$ & $\begin{array}{l}0.251 \\
0.24 \mathrm{~S} \\
0.261 \\
0.29 \mathrm{~S}\end{array}$ & $\begin{array}{l}1: 3.7 \\
1: 1.2 \\
1: 3.5 \\
1: 0.9\end{array}$ \\
\hline 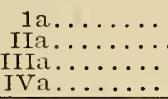 & $\begin{array}{l}51.42 \\
15.59 \\
57.25 \\
19.69\end{array}$ & $\begin{array}{r}9.1 \mathrm{~S} \\
2.78 \\
10.23 \\
3.51\end{array}$ & $\begin{array}{l}0.809 \\
0.249 \\
0.934 \\
0.321\end{array}$ & $\begin{array}{r}13.94 \\
15.67 \\
8.03 \\
8.15 \\
\end{array}$ & $\begin{array}{l}2.49 \\
2.79 \\
1.43 \\
1.45 \\
\end{array}$ & $\begin{array}{l}0.220 \\
0.251 \\
0.131 \\
0.133\end{array}$ & $\begin{array}{l}1: 3.7 \\
1: 1 \\
1: 7.2 \\
1: 2.4\end{array}$ \\
\hline
\end{tabular}


that should be retained during the first year of the experiment and considerably less than is required for retention during the latter part of the experiment. The amount of phosphorus probably was ample throughout the entire experiment. Group III was fed an abundance of calcium and probably enough phosphorus during the first year, but during the second year the amount of phosphorus was considerably less than is required for retention. Group IV also was fed just about the amount of calcium that should be retained, and during the first year probably was fed sufficient phosphorus. During the last year, however, the phosphorus was considerably below the amount which is required for retention.

Table 7.-Average Daily Amount of Calcium and of Phosphorus Consumed by the Animals in Each Group, and Average Daily Amount of Each Consumed per 100 Pounds of Live Weight of the Animals, by Periods

\begin{tabular}{|c|c|c|c|c|c|}
\hline $\begin{array}{l}\text { Period End- } \\
\text { ing When } \\
\text { Animals } \\
\text { Were at } \\
\text { Age of }\end{array}$ & 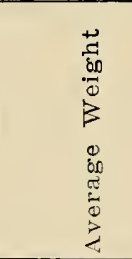 & 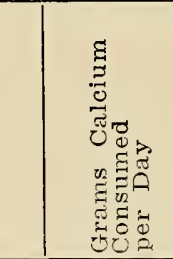 & 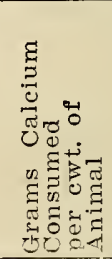 & 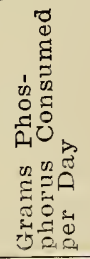 & 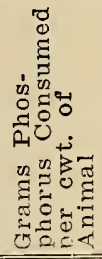 \\
\hline \multicolumn{6}{|c|}{ GROUP I. NORMAL GROUP } \\
\hline 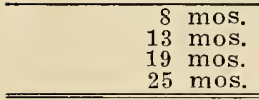 & $\begin{array}{l}196 \\
408 \\
646 \\
880 \\
\end{array}$ & $\begin{array}{l}25.7 \\
45.7 \\
54.9 \\
64.2 \\
\end{array}$ & $\begin{array}{r}13.1 \\
11.2 \\
8.5 \\
7.3 \\
\end{array}$ & $\begin{array}{r}9.3 \\
13.0 \\
14.4 \\
16.9 \\
\end{array}$ & $\begin{array}{l}4.7 \\
2.5 \\
2.2 \\
1.9 \\
\end{array}$ \\
\hline \multicolumn{6}{|c|}{ GROUP II. LOW-CALCIUM GROUP } \\
\hline $\begin{aligned} & 8 \text { mos. } \\
& 13 \text { mos. } \\
& 19 \text { mos. } \\
& 25 \text { mos. } \\
&\end{aligned}$ & $\begin{array}{l}184 \\
381 \\
585 \\
750 \\
\end{array}$ & $\begin{array}{r}13.1 \\
14.5 \\
16.6 \\
20.1 \\
\end{array}$ & $\begin{array}{l}7.1 \\
3.8 \\
2.8 \\
2.1 \\
\end{array}$ & $\begin{array}{r}8.6 \\
13.5 \\
15.0 \\
17.3 \\
\end{array}$ & $\begin{array}{l}4.7 \\
3.5 \\
2.5 \\
2.3 \\
\end{array}$ \\
\hline \multicolumn{6}{|c|}{ GROUP III. LOW-PHOSPHORUS GROUP } \\
\hline $\begin{array}{r}8 \text { mos. } \\
13 \text { mos. } \\
19 \text { mos. } \\
25 \text { mos. }\end{array}$ & $\begin{array}{l}192 \\
395 \\
617 \\
833 \\
\end{array}$ & $\begin{array}{l}24.7 \\
44.8 \\
60.8 \\
71.3\end{array}$ & $\begin{array}{r}12.9 \\
11.3 \\
9.8 \\
8.5\end{array}$ & $\begin{array}{r}9.2 \\
13.5 \\
8.5 \\
10.0\end{array}$ & $\begin{array}{l}4.5 \\
3.4 \\
1.2 \\
1.2 \\
\end{array}$ \\
\hline \multicolumn{6}{|c|}{ GROUP IV. LOW-CALCILM-LOW-PHOSPHORIS GROUP } \\
\hline $\begin{array}{r}8 \text { mos. } \\
13 \text { mos. } \\
19 \text { mos. } \\
25 \text { mos. }\end{array}$ & $\begin{array}{l}180 \\
366 \\
570 \\
731\end{array}$ & $\begin{array}{l}11.3 \\
13.6 \\
20.0 \\
22.3\end{array}$ & $\begin{array}{l}6.3 \\
3.7 \\
3.5 \\
3.0\end{array}$ & $\begin{array}{r}9.4 \\
15.0 \\
8.2 \\
9.1\end{array}$ & $\begin{array}{l}5.2 \\
4.1 \\
1.4 \\
1.2\end{array}$ \\
\hline
\end{tabular}

If the optimum requirements for calcium and phosphorus, as found by McCollum for rats as given above, is applied to the rations for dairy calves, it will be seen that Rations II, IV, IIa, and IV a are all below the optimum requirements for calcium, and that all of the rations are considerably below the optimum requirements for phosphorus.

The amount of phosphorus and calcium required in a ration depends largely upon the retention of these elements by the animal. It is of no use to feed a large amount of these elements if they are not retained. No definite results have been obtained as to the percentage of these elements which are retained in the body. It is now known that this depends upon several factors. 
Ratio of Calcium and Phosphorus. That a proper ratio between the amount of calcium and phosphorus in a ration is important has been shown by several workers.

McCollum and co-workers (1.921a) found that in the rat the profound disturbances in the deposition of lime salts in cartilage and bone and the changes in the cells of those tissues which give rise to rickets, may be produced by a disturbance in the diet of the optimal ratio between calcium and phosphorus. They stated that it would seem that in so far as calcium and phosphorts are concerned the proper ratio between the two is of vastly more importance in insuring normal calcification than the absolute amount of the elements themselves.

Haag and Palmer (1928) with rats obtained results which indicated that a more or less balanced condition of calcium, magnesium, and phosphorus salts in the ration is essential to normal growth and functioning.

Gullickson and Eckles (1927), however, with growing dairy heifers did not notice any ill effects of feeding rations in which the phosphorus content almost invariably exceeded the calcium content-most of the time by nearly two to one.

The rations under study varied greatly in the ratio between calcium and phosphorus. Ration IIIa had a ratio of phosphorus to calcium of 1 to 7.2, while Ration IV had a ratio of 1 to 0.9 . The others varied between these two extremes.

Factor Which Assists in the Assimilation of Calcium and Phosphorus. That there is a specific factor connected with the assimilation of calcium and phosphorus was first shown by Mellanby (1919), but he associated it with vitamin A. McCollum, Simmonds, and Becker (1922) clearly demonstrated the existence of a vitamin distinct from vitamin $A$ which regulates the metabolism of the bones. That this vitamin is carried in green plant tissues has been shown by Hart and associates (192.3 $t$ ). They have shown that green plant tissue contains more of this vitamin than plant tissue exposed to long curing processes, and that alfalfa hay when fed as a supplement to grains and grain by-products may be so cured as to retain qualities of this vitamin sufficient to maintain liberal milking cows in positive calcium and phosphorus balance. Under practical conditions of curing hay in the windrow with exposure to air and light, the hay is not capable of maintaining calcium and phosphorus equilibrium in milking cows. Hart and associates (1924) also have shown that the ultra-violet rays have a beneficial influence upon the assimilation of calcium and phosphorus by milking goats.

In this experiment no attempt was made to control the effects of this factor. Alfalfa hay was fed to Groups I and III, but it was of such a nature that it is doubtful that very much of this factor was available. Sunlight likewise was not a factor, since the heifers were kept indoors continuously, and any sunlight reaching them first passed through the window glass. 


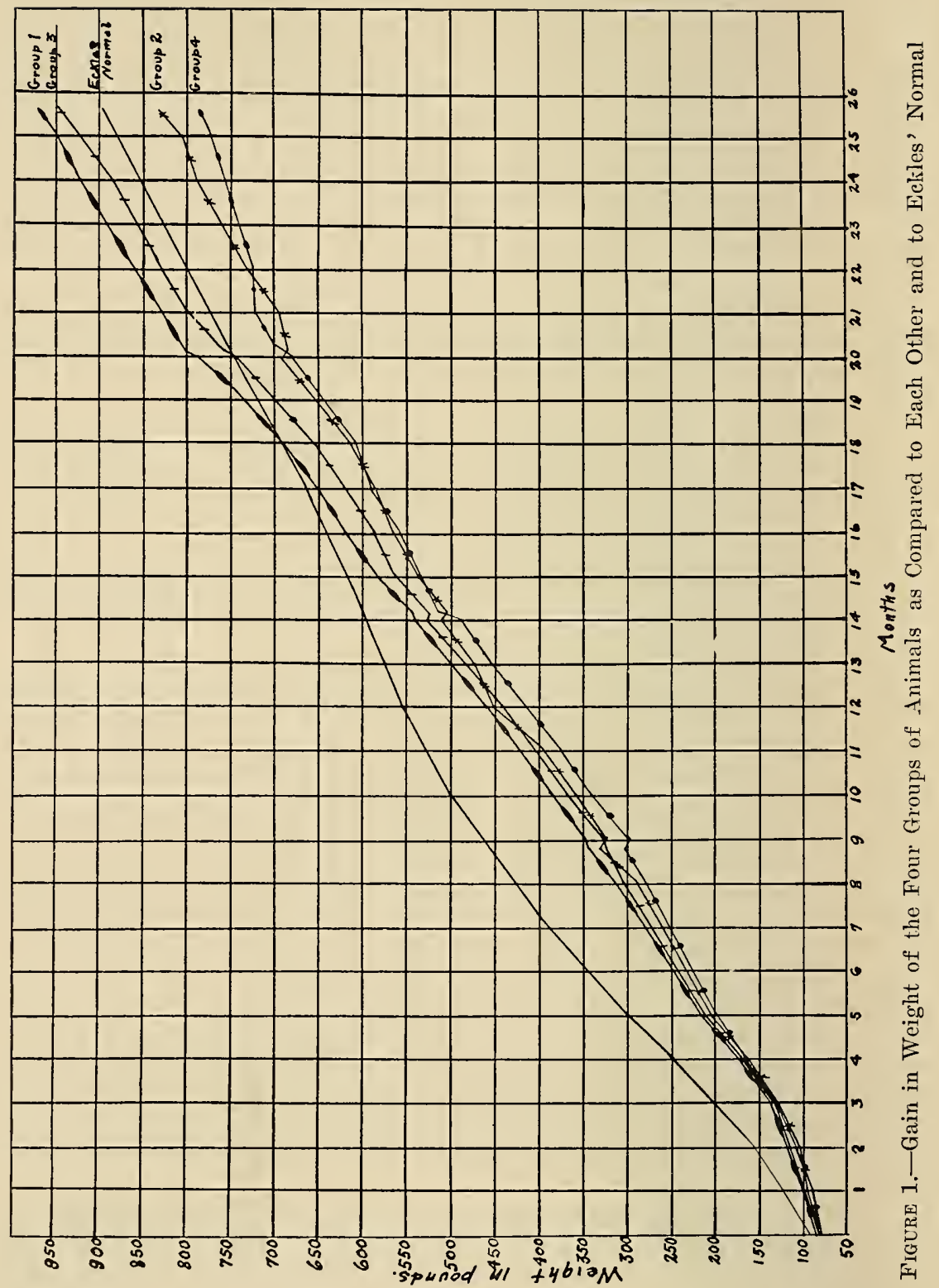




\section{RESULTS OF THE EXPERIMENT}

\section{Effect of Rations on Growth and Development of the Animals}

Grouth. The gain in weight and in leight at withers is shown by Figures 1 and 2. The arerage monthly gains are shown by periods in Tables 8 and 9, where they are also converted to a percentage basis, using the normal-fed group as the basis of conıarison.

It will be noted that during the first year none of the groups averaged as large as the figures given by Eckles (1920) for the normal purebred Holstein. The animals may not have been of as large a strain as those used by Eckles, but more probably the difference was due to the start which they received. As stated before, the calves when quite young were shipped a distance of several hundred miles TABLE 8.-Average Honthly Gain in if eight of Animals in, the Farious Groups, by Periods; Fxpressed ulso as Percentege of the Normal Group

\begin{tabular}{|c|c|c|c|c|c|c|c|}
\hline $\begin{array}{l}\text { Period End- } \\
\text { ing When } \\
\text { Animals } \\
\text { Were at } \\
\text { Age of }\end{array}$ & 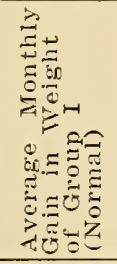 & 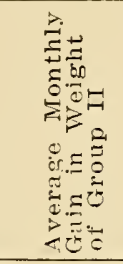 & 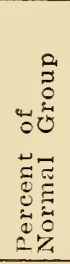 & 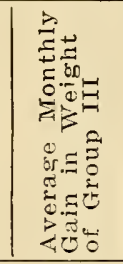 & 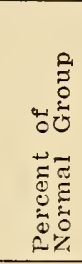 & 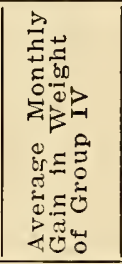 & 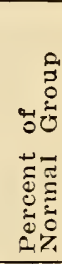 \\
\hline $\begin{array}{r}8 \text { mos. } \\
13 \text { mos. } \\
19 \text { mos. } \\
25 \text { mos. }\end{array}$ & $\begin{array}{c}\text { (Founds) } \\
27.75 \\
38.93 \\
35.76 \\
31.36 \\
\end{array}$ & $\begin{array}{c}\text { (younds) } \\
25.55 \\
37.77 \\
31.35 \\
23.92 \\
\end{array}$ & $\begin{array}{l}92.1 \\
97.0 \\
87.6 \\
76.3\end{array}$ & $\begin{array}{c}\text { (pounds) } \\
27.47 \\
37.36 \\
32.60 \\
33.93\end{array}$ & $\begin{array}{r}99.0 \\
96.0 \\
91.4 \\
108.2\end{array}$ & $\begin{array}{l}\text { (pounds) } \\
24.81 \\
34.94 \\
32.73 \\
17.17\end{array}$ & $\begin{array}{l}89.4 \\
89.7 \\
91.5 \\
54.8\end{array}$ \\
\hline
\end{tabular}

in the coldest part of the winter and many of them had a long sick period before they were able to start normal growth. Beginning when they were about 13 months of age the animals in all groups made very good gains. Those in Groups I and III passed the Eckles normal growth curve both in weight and in height at withers and at the end of the experiment averaged more than 50 pounds in weight over those used to establish the Eckles normal, and were also considerably above them in height at withers.

The animals in Groups II and IV, however, failed by more than 50 pounds to reach the size of the Eckles normal in weight and were also below them in height at withers. 'The animals in all of the groups were still growing at the end of the experiment. The rate of gain, however, was considerably slower than at first.

It will be seen that the animals in Group I in most cases grew faster than the animals in the other groups, although the animals in Group III gained almost as well as did the normal-fed group, especially in weight. They did not seem to gain as well, however, in height at withers, especially during the last periods.

The animals in Groups II and IV grew almost as well as the animals in the normal-fed group during the first two periods, but during the last two periods they failed to gain as rapidly either in weight or in height at withers. At the end of the experiment they averaged 


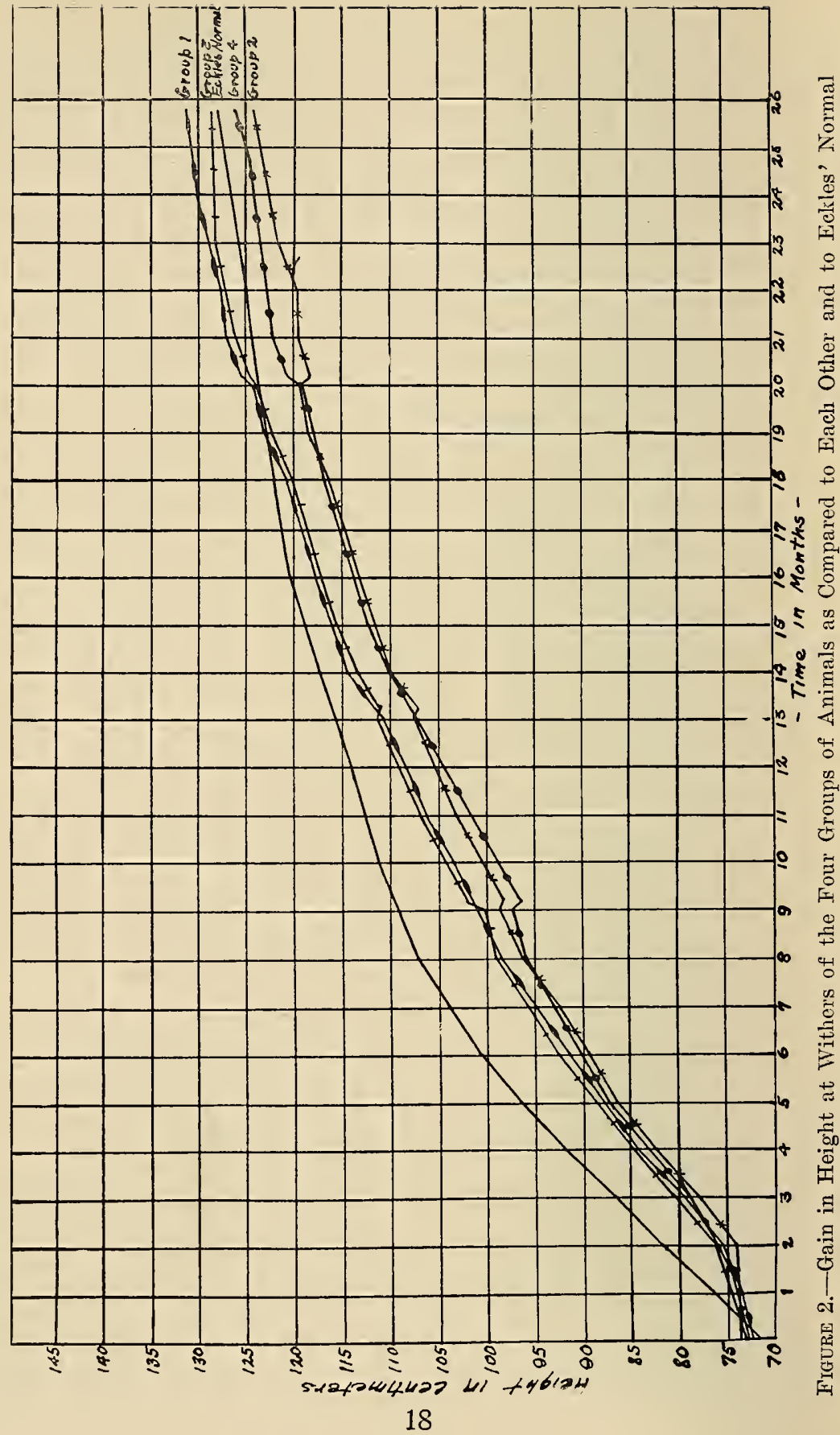


more than 100 pounds less in weight and more than 5 centimeters (2 inches) less in height at withers than the animals fed the normal ration.

Discussion of Results. It would seem that the slower growth made by the animals in Groups II and IV as compared to those in Groups I and III must be due to the lower calcium content of the ration. It will be noted that these two groups (II and IV) were both low in calcium throughout the experiment. Group IV was low also in phosphorus during the last two periods. However, the animals in Group III also were low in phosphorus during the same two

TABLE 9.-Average Monthly Gains in Height at Withers of Animals in the Various Groups; Expressed also as Percentage of the Normal Group

\begin{tabular}{|c|c|c|c|c|c|c|c|}
\hline $\begin{array}{l}\text { Period End- } \\
\text { ing When } \\
\text { Animals } \\
\text { Were at } \\
\text { Age of }\end{array}$ & 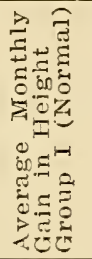 & 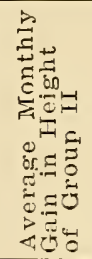 & 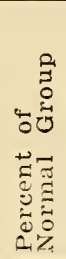 & 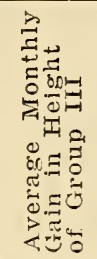 & 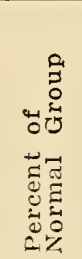 & 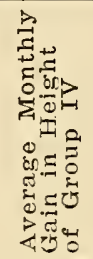 & 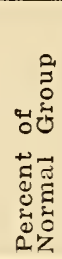 \\
\hline $\begin{array}{l}8 \text { mos. } \\
13 \text { mos. } \\
19 \text { mos. } \\
25 \text { mos. }\end{array}$ & $\begin{array}{l}\text { (cms.) } \\
3.31 \\
2.45 \\
1.94 \\
1.00\end{array}$ & $\begin{array}{l}\text { (cms.) } \\
2.83 \\
2.30 \\
1.84 \\
0.74\end{array}$ & $\begin{array}{l}85.5 \\
93.8 \\
94.8 \\
74.0\end{array}$ & $\begin{array}{l}\text { (cms.) } \\
3.23 \\
2.70 \\
1.74 \\
0.85\end{array}$ & $\begin{array}{r}97.6 \\
110.2 \\
89.5 \\
85.0\end{array}$ & $\begin{array}{l}\text { (cms.) } \\
2.93 \\
2.27 \\
1.75 \\
0.83\end{array}$ & $\begin{array}{l}88.5 \\
92.6 \\
90.2 \\
83.0\end{array}$ \\
\hline
\end{tabular}

periods but still made gains almost equal to normal for some time. Table 3 shows that the animals in both Groups II and IV consumed slightly more digestible crude protein per hundredweight of the animals and per pound of gain than did those in Groups I and IIl. The difference in growth therefore must have been due to some factor other than protein and total nutrients. It is possible that the greater growth may have been due to some factor contained in the alfalfa hay which was included in the rations of Groups I and III and not in those of Groups II and IV. However, the only great difference as far as could be noted by chemical analyses was in the calcium content.

It has been found by several investigators that animals will still continue to gain in weight and especially in height at withers under adverse conditions as to nutrition. Eckles (1915) found that deficient rations fed to growing heifers restricted gain in weight more than in height at withers. This same result was found by Reed, Fitch, and Cave (1924) and by Davis and co-workers (1922). It has been shown by Trowbridge and co-workers $(1915,1918)$ and by Moulton and coworkers (1918) that young steers maintained at constant weight even on a sub-normal plane of nutrition continued to grow in height and in width of skeleton. They found that although the scantily fed steers grew less rapidly in all respects, they attained the same height at maturity as a group of full-fed steers. They tended to recover it by making more rapid gains when put on full feed and by continuing to grow for a longer period of time. 
Investigators have not found, howerer, that rations low in calcium or low in phosphorus retard growth. Eckles and Swett (1918) found that the heifer fed a low-calcium ration continued to grow just as well as one which was being fed normally. The heifer at last became stiff and had difficulty in getting up and walking but gained normally up until this time. Similar results were obtained by Aron and Sebauer (1908) with dogs; by Maynard and co-workers (1925), Bohstedt (1926), and other investigators with pigs which were fed rations low in calcium; and by Hart and co-workers (1909) with pigs which were fed rations low in phospnorus. The animals in these cases continued to grow normally for some time, often up until the time of complete collapse.

On the other hand the cattle grown in the deficiency areas were almost invariably stunted. Eckles, Becker, and P'almer (1926) found that cattle grown in such areas in western Minnesota were decidedly stunted in size. Animals 4 years of age on some farms weigh less than 600 pounds as compared to a normal of 1,000 to 1,100 pounds for animals of similar size and breeding. Cattle were also reported stunted by Theiler and co-workers (1924), Tuff (1924), and by Hart and co-workers (1927). These report that after bonemeal is fed, the cattle make rapid gains. The trouble in these areas is caused by the
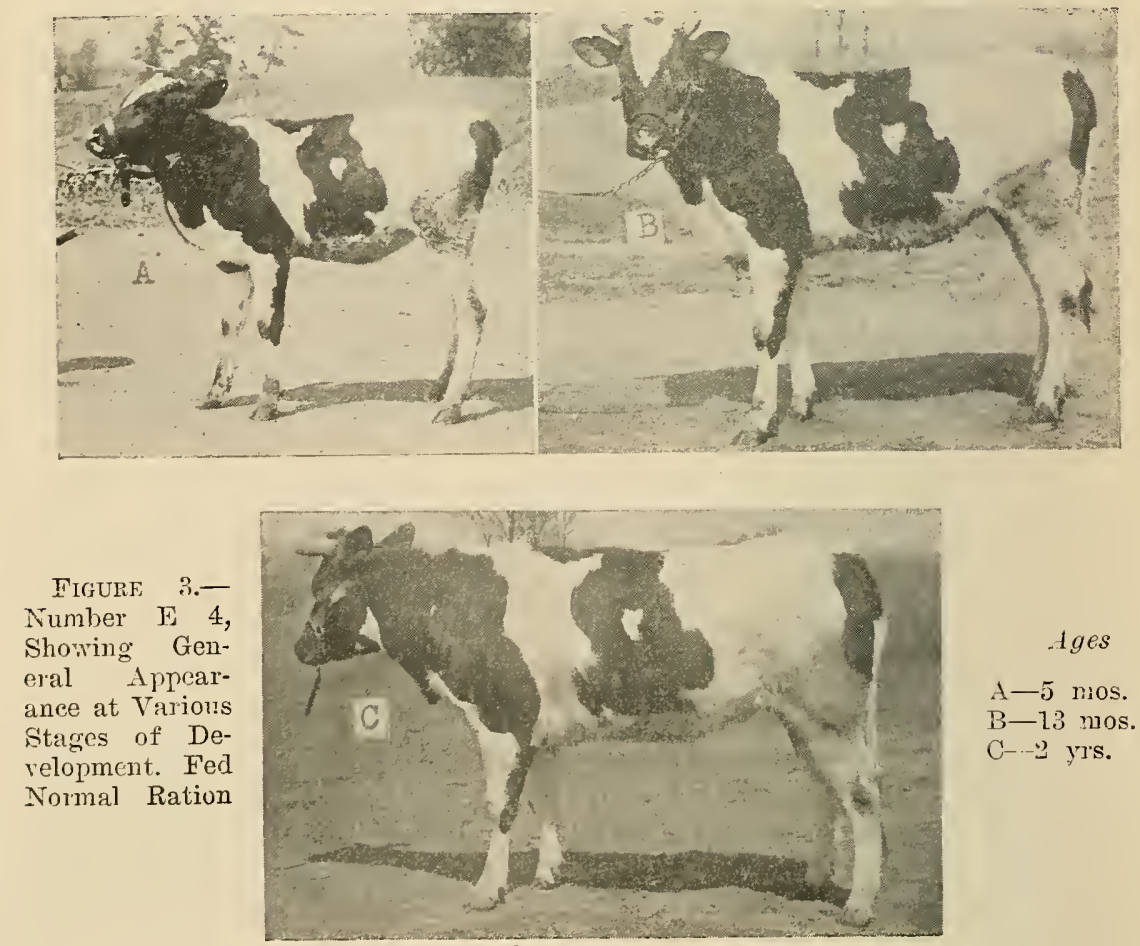
low phosphorus content of the feed produced. The stunted condition may be caused by the fact that the animal fed such rations does not consume enough for normal growth, but just as soon as the deficiency is replaced it begins to grow and to take on weight in the normal manner. This, however, was not true with the animals in the present experiment. All were fed according to their requirements as to digestible crude protein and digestible nutrients. These, however, did not appear to utilize their feed as well as did the normal-fed animals, since they consunned more digestible crude protein and digestible nutrients per pound of gain and per 100 pounds of live weight than did the normal-fed group.

The animals in Groups II, III, and IV continued to gain in weight practically as well as in height at withers in comparison with the animals in the normal-fed group.

In summary, dairy animals fed rations low in calcium or low in both calcium and phosphorus may continue to grow in weight and in height at withers for some time almost as well as dairy animals fed a normal ration, but over a period of two years they will not make the gains either in weight or height at withers as will animals fed i normal ration. The animals fed rations low in phosphorus, however, continued to grow almost as well as did the normal-fed group.

Physical Abnormalitics. Figures 3 to 10 inclusive show pictures of representatives of each group at various stages of development.

All animals in Group I developed normally as far as general appearances were concerned. There were, of course, considerable differences in appearance, but no more than could be attributed to individuality.

All the animals in Group II developed normally as far as general appearances were concerned. They were not as large as the animals in Group I but otherwise appeared normal.

In Group III, No. E 20, the largest and fastest growing heifer in the group, became stiff in her joints in September, 1927, at 19 months of age, or 5 months after being put on Ration VIIa, which was very low in phosphorus. At the time the stiffness appeared she refused her feed for several days and seemed to be in considerable pain. She gradually recovered her appetite and continued to grow normally, but her legs never fully recovered from their stiffiness and were slightly bent, as slown in Figure 11, the picture being taken in April, 1928. No. E 21, the mate of No. E 20, was a short-legged, sturdy type of heifer, and as far as could be noted her legs remained normal. Her back, however, did take on a slight sway at about the same age, whereas it had been straight when she was younger.

In Group IV, No. E 31 when a calf had a very severe case of scours and it was uncertain for some time whether she would recover. She gradually did recover but was never a thrifty, 1lormal-looking or acting calf. In January and February, 1927, when she was about a year old, she became very nervous. Whenever anyone would enter her stall she would tremble violently. On January 25, 1927, and again on February 23, 1928, 4 months after she had received no milk and 
was on the low-calcium-low-phosphorus ration, she suffered a fit-like spasm. She fell over in her stall, frothed at the mouth, became stiff, and lay prostrate. These symptoms were very similar to those noted when calves were fed milk or milk and grain as the sole diet, as reported by McCandlish (1923) and Reed and Huffman (1925). The joints in her legs became swollen and her legs slightly bent. For several weeks she failed to gain in weight or height. However, she seemed to gain a little shortly before she was slaughtered, April 1, 1927. Probably the rveakened condition of the calf, combined with the abnormal ration, brought on such trouble in this calf when more hardy calves, fed similar rations, seemed normal. If such was the case the amount of calcium in such a ration certainly must have been below the optimal requirements in calcium for such animals.

The other calves on this ration seemed to grow normally, although at a slower rate than the normal-fed group, until about September, 1927, when No. E 28 developed a sway in the back. This calf, as shown in Figure 9, had a straight back when she was a calí but gradually developed a sway until at the time of her death, April, 1928, she was extremely sway-backed. This is shown in Figure 12. Her
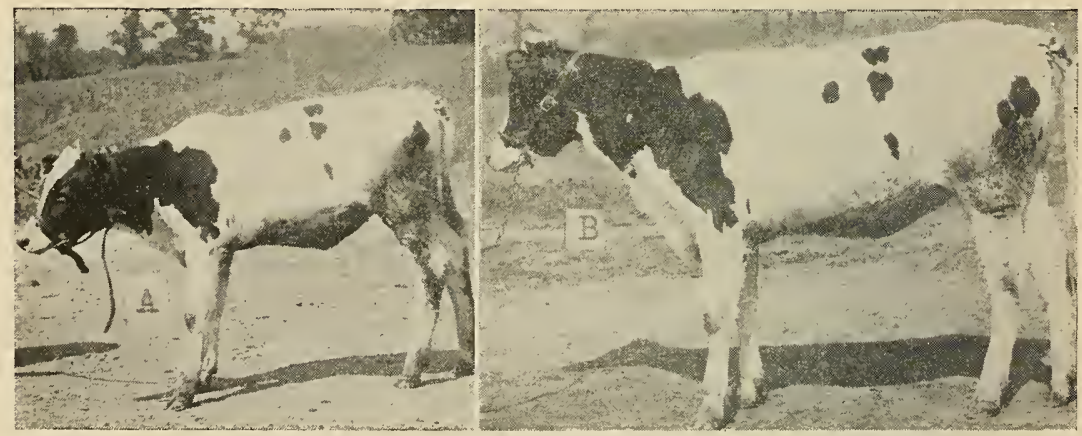

Firure 4.Number E 5, Showing General Apnearance at Various Stages of Development. Fed Normal Ration

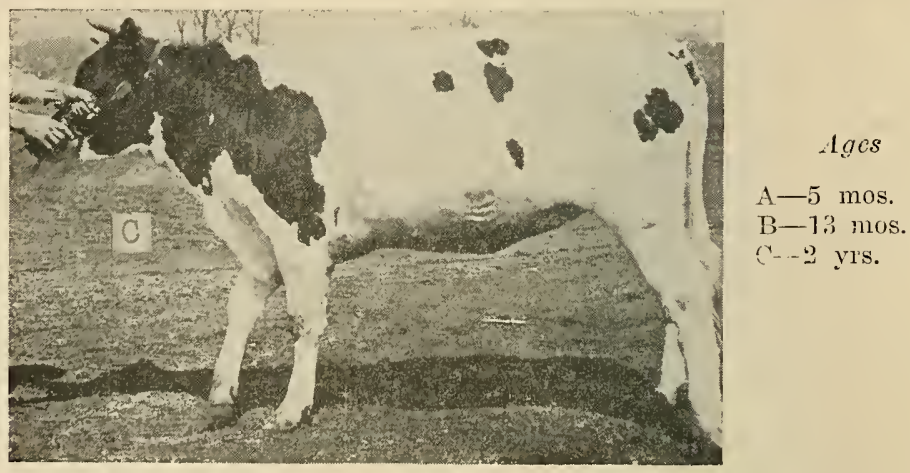


legs also were not very straight at this time. It is very doubtful if this heifer could have withstood the strain incident to pregnancy and lactation. She appeared to be getting worse as she grew older.

No. E 29, the mate of No. E 28, however, did not develop as abnormally in this respect. She was an extremely healthy heifer from the start and as a calf had a very straight, strong back. It could be noted, however, that her back had begun to sway toward the end of the experiment, but this was not nearly as evident as it was with No. E 28 .

These observations suggest the possibility that swaybacks in mature animals are partially due to the ration which the heifers receive when growing, but that the individuality of an animal may partially overcome defects in the ration. A good strong individual may be able to withstand poorer rations than animals that are not as strong. This may be due to the greater storage of minerals that the stronger individual may have stored up when younger.

Abnormal Cravings. Most of the animals, even those fed the normal rations, chewed the wood in their stalls. This began at an early age, even before they were weaned from milk, and continued throughout the experiment. The animals in the normal group seemed just as abnormal in this regard as the others. Some of the animals ate a few shavings with which they were bedded, but this habit, too, seemed just as strong with the normally fed group as with the others.

Drinling Habits. The animals in Groups III and IV developed the habit toward the last of the experiment of grinding their teeth. They would stand for 15 to 20 minutes at a time grinding their teeth with a peculiar noise.

The animals in these two groups and also those in Group II developed the habit of lapping the water with their tongues in cold weather. Some of them would froth considerably at time of drinking. No. E 12 in Group II, Nos. E 20 and E 21 in Group III, and Nos. E 28, E 29, and E 30 in Group IV all showed this characteristic before they were slaughtered. No. E 28 in Group IV and No. E 20 in Group III were probably the worst in this habit.

$\mathrm{W}^{\top}$ hen the teeth were examined at time of slaughter it was found that they had become so badly worn that some of them were down to the gums. The teeth of the animals in Groups II, III, and IV were all badly worn at the end of the experiment, although the teeth even of Group I were worn to some extent. They, however, were not worn nearly so badly as were those of the other groups. 'The same condition was noted by Reed and Huffman (1928) when they fed a lot of heifers raw rock phosphate in their ration. The teeth of these animals became sensitive to cold water when they were about $2 \mathrm{I} / 2$ years of age. An examination of their mouths revealed that the raw rock phosphate had brought about a softening of the teeth and in some instances the teeth were worn down to the gums. 
TABLE 10.--Age at First Signs of Oestrum, Total Number of Times Noted, and Regularity of Oestrum

\begin{tabular}{|c|c|c|c|c|c|}
\hline \multirow{2}{*}{$\begin{array}{l}\text { Number } \\
\text { of Calf }\end{array}$} & \multicolumn{3}{|c|}{ Age at First Signs of Oestrum } & \multirow{2}{*}{$\begin{array}{l}\text { Number of } \\
\text { Times } \\
\text { Noted }\end{array}$} & \multirow{2}{*}{$\begin{array}{l}\text { Regularity } \\
\text { of Oestrum }\end{array}$} \\
\hline & Years & Months & Days & & \\
\hline \multicolumn{6}{|c|}{ GROUP I. NORMAL GROUP } \\
\hline $\mathrm{E}-3$ & 1 & 1 & 11 & 10 & regular \\
\hline $\mathrm{E}-4$ & $\frac{1}{1}$ & 0 & 4 & 14 & regular \\
\hline E-5 & 1 & 1 & 22 & 13 & regular \\
\hline $\begin{array}{l}\mathrm{E}-6 \\
\mathrm{E}-7\end{array}$ & $\begin{array}{l}1 \\
0\end{array}$ & ${ }_{11}^{3}$ & $\begin{array}{l}20 \\
20\end{array}$ & $\begin{array}{l}6 \\
1\end{array}$ & $\begin{array}{l}\text { fairly regular } \\
\text { regular }\end{array}$ \\
\hline Average & 1 & 1 & 9 & $10.8 *$ & \\
\hline \multicolumn{6}{|c|}{ GROUP II. LOW-CALCIUM GROUP } \\
\hline $\mathrm{E}-11$ & 1 & 0 & 25 & 11 & regular \\
\hline $\mathrm{E}-12$ & 1 & 9 & 23 & 5 & il'regular \\
\hline $\begin{array}{l}\mathrm{E}-13 \\
\mathrm{E}-14\end{array}$ & $\begin{array}{l}1 \\
1\end{array}$ & $\begin{array}{l}0 \\
3\end{array}$ & 11 & 5 & $\begin{array}{l}\text { very irregular } \\
\text { fairly regular }\end{array}$ \\
\hline $\mathrm{E}-15$ & 0 & 10 & 8 & 2 & regular \\
\hline Average & 1 & 2 & 18 & $6.8^{*}$ & \\
\hline \multicolumn{6}{|c|}{ GROUP III. LOW-PHOSPHORUS GROITP } \\
\hline E-19 & 1 & 2 & 29 & 12 & regular \\
\hline $\mathbf{E}-20$ & 1 & 3 & 13 & 9 & irregular \\
\hline $\begin{array}{l}\mathrm{E}-21 \\
\mathrm{E}-22\end{array}$ & 0 & 11 & 28 & 21 & regular \\
\hline 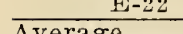 & 1 & 1 & 13 & & regular \\
\hline Average & 1 & 1 & 28 & 15.0 & \\
\hline \multicolumn{6}{|c|}{ GROUP IV. LOW-CALCIUM-LOW-PHOSPHORLS GROUP } \\
\hline $\mathrm{E}-27$ & 1 & 3 & 16 & 7 & fairly regular \\
\hline E-28 & 1 & 4 & 20 & 10 & irregular \\
\hline E-29 & 1 & 4 & 5 & 10 & irregular \\
\hline $\mathrm{E}-30$ & 1 & 1 & 7 & 3 & irregular \\
\hline Average & 1 & 3 & 12 & 7.5 & \\
\hline
\end{tabular}

*Average of first four animals only.

\section{Effect of Rations upon the Oestrum of the Animals}

Records were kept of the time the heifers in the varions groups showed signs of oestrum. Of course some may have been missed but the attendant was on the watch at all times and recorded all that were noted. Table 10 gives the age of the heifers at the time of the first signs of oestrum, together with the total number of times of oestrum noted and the regularity of oestrum of the different heifers in the experiment.

Nos. E 1, E 2, E 8, E 9, E 10, E 16, E 17, E 18, E 23, E 24, E 25, E 26, E 31, and E 32 were slaughtered before they showed signs of oestrum.

It will be noted that the normal group averaged 1 year, 1 month, and 19 days of age at the time of the first sign of oestrum. They varied from 11 months and 20 days to 1 year, 3 months, and 20 days. All were fairly regular in the period between signs of oestrum, and were observed showing signs of oestrum a total of 44 times.

The animals in Group II averaged 1 year, 2 months, and 18 days of age when they first showed signs of oestrum. They were 1 month and 18 days older on the average than the normal group. No. E 12 did not show signs of oestrum until an advanced age, which was largely responsible for this difference. The animals were noted show- 
ing signs of oestrum a total of 27 times, or 17 times less than Group 1. As a group, the period between signs of oestrum was irregular.

The animals in Group III averaged 1 year, 1 month, and 28 days of age when they first showed signs of oestrum. This was only 19 days older than the average of the animals in the normal group. They were observed showing signs of oestrum a total of 52 times, or 8 times more than the animals in the normal group. They were fairly regular in period between times of oestrum. Since their ration was not greatly different from that of Group I in its calcium and phosphorus content up until the animals were a year old, very little difference in time of first signs of oestrum between the animals in this group and those in Group I would be expected.

The animals in Group IV areraged 1 year, 3 months, and 12 days when they first showed signs of oestrum. This was 2 months and 3 days older than the aninals fed the normal ration. They were observed to show signs of vestrum a total of 30 times, or 14 times less than the group fed the normal ration. They were quite irregular in the period between times of oestrum.

Discussion of Results. The results indicate that the heifers in Groups I and III showed signs of oestrum when they were $11 / 2$ to 2 months younger than the heifers in Groups II and IV.

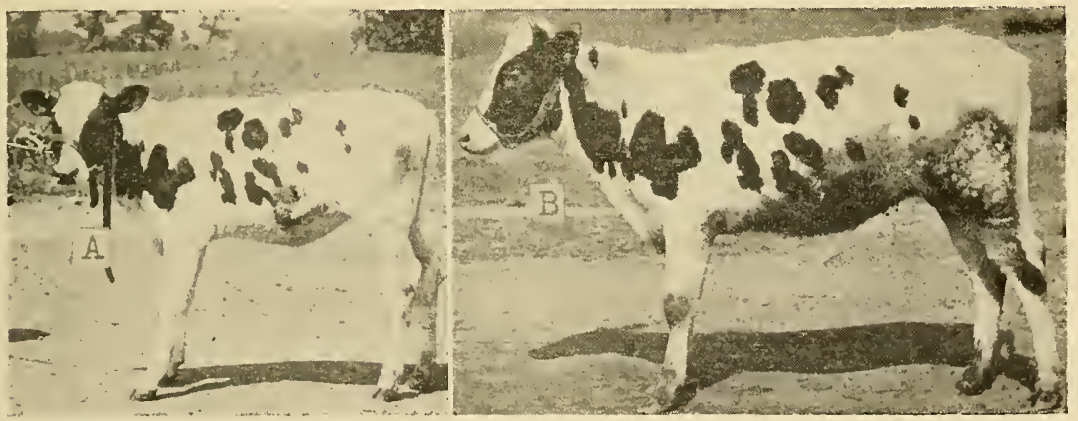

Figure 5.Number E 12, Showing Genaral Appearance at Various Stages of Dewopment. Fed Low - Calcium Fiation

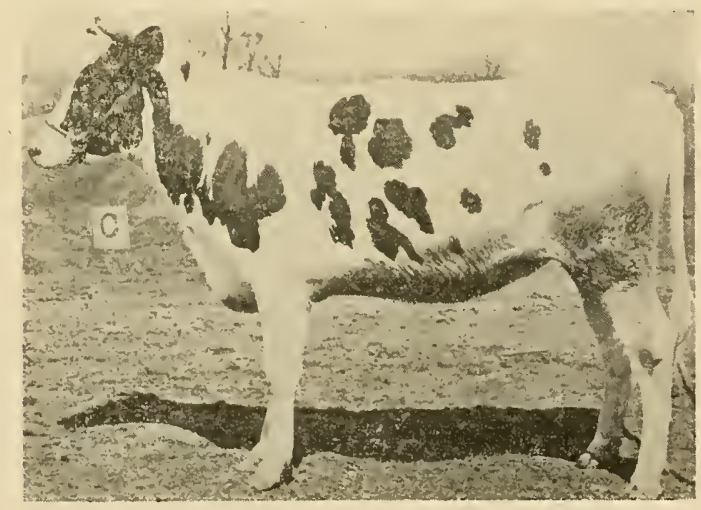

Agcs $1-5$ mos. J-13 mos. D--2 yus. 
The heifers in Groups I and III also were much more regular in period between times of oestrum than were the heifers in the other two groups.

This is in agreement with results obtaincd by other investigators, as there is found evidence in literature which indicates that rations quite low in the minerals often cause serious disturbances in reproduction. Eckles, Becker, and Palmer (1926) found that in the deficient area in western Minnesota considerable trouble was experienced with breeding. On many farms the cows were not expected to produce a calf more than once in two years. Heifers often did not show signs of oestrum until two years of age. The average calf crop in the worst-affected districts, as observed after a dry season, was estimated at less than 50 percent of the normal. Tuff (1924) also found that in seasons of low rainfall the trouble incident to reproduction in the cattle in deficient areas of Norway was increased. The cattle seem to fail to ovulate. Meigs and Woodward (1921) also found difficulty in reproduction when cows were fed a ration low in calcium. Jordan, Hart, and Patten (1906), studying the physiological effect of certain phosphorus compounds, found that when cows were fed rations very low in phosphorus they showed entire cessation of oestrum. Hart and co-workers (1924) in working with the rations derived from the oat and wheat plants found that normal reproduction would not
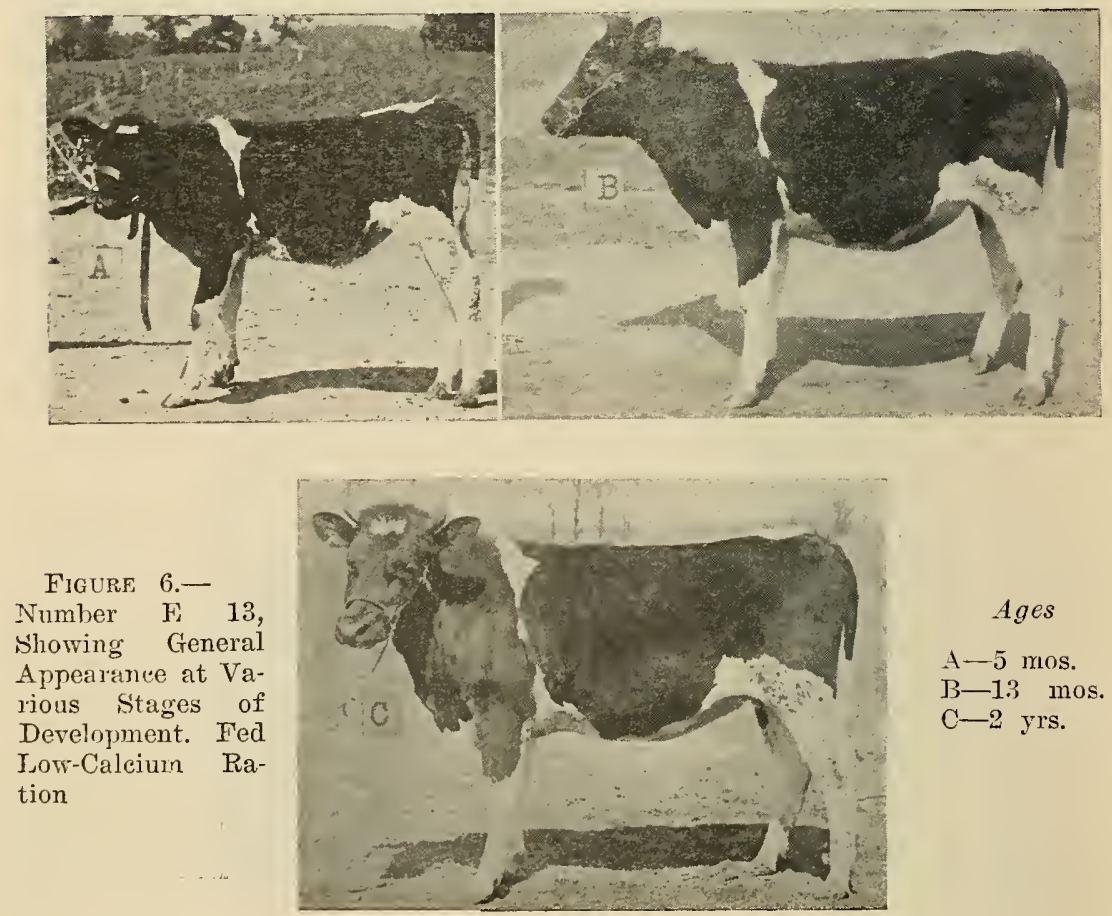
take place on account of lack of calcium. They state that 0.45 percent $\mathrm{CaO}$ in the ration is the least amount which can be fed in a ration to insure normal reproduction.

It can be seen by referring to Table 6 that the rations fed to the animals in Groups II and IV were slightly below the amount stated by Hart and co-workers to be the least amount of calcium that could be fed to insure normal reproduction. In their studies, however, the animals conceived but failed to drop normal offspring, or would abort. The animals in the present experiment were not bred.

\section{Effect of the Rations upon the Calcium and Inorganic Phosphorus Content of the Blood}

Since the blood carries the food nutrients to the parts of the body where they are needed, it would naturally be supposed that a lack of any required nutrient in the food would result in a lower concentration of this nutrient in the blood. This, however, is not always the case, since the blood is maintained fairly uniform in its constitution, even in time of low supply, by using some of the reserve supply which has been stored up in various parts of the body.

The calcium and inorganic phosphorus content of the blood, however, has been used for several years as a criterion in the demonstration of rickets in animals. Steenbock and co-workers (1923) used it as a criterion in the demonstration of the existence of a specific antirachitic vitamin. They were able to increase the calcium and inorganic phosphorus in the serum of dogs fed rachitic rations by the addition of cod-liver oil. They were also able to increase the concentration of calcium and inorganic phosphorus in the serum of chickens by the addition of cod-liver oil to a ration which otherwise caused leg weakness.

A study was therefore made of the blood of the animals in the present experiment to determine the effect of the rations upon its calcium and inorganic phosphorus content.

Analyses of Blood. Samples of blood were taken from each animal in the experiment at 9-month intervals and analyzed for calcium and inorganic phosphorts by the Briggs (1922, 1924) modification of the Bell and Doisy (1920) method.

The samples were taken from the jugular vein of the animals at the same hour each day in order that the samples might be as uniform as possible. After the first two times samples were taken on 3 consecutive days, and a composite of each day's sampling was used for the analyses.

Calcium. The average results obtained with the calcium analyses for each period are given in Table 11.

Table 11 shows that the rations had very little effect upon the calcium content of the blood. The blood of the calves fed the rations low in calcium had just as much calcium in it as the biood of the animals fed rations rich in calcium. Possibly if the calcium content of the rations had been somewhat lower, the blood would have been affected. 
It can be noted also that in general, as the animal became older, there was a slight diminution in the calcium concentration of the blood.

Phosphorus. The average results obtained with the phosphorus analyses for each period are given in Table 12.

Table 12 indicates that the rations fed to animals exert a very profound influence upon the inorganic phosphorus content of the blood. When the ration fed contained ample phosphorus, as they all did in the first two periods of the trial, the inorganic phosphorus content of the blood remained normal. However, just as soon as the phosphorus in the feed was lowered, the inorganic phosphorus content of the blood also went down.

There appears some evidence that dairy animals are unable to keep the inorganic phosphorus content of their blood normal if they do not obtain sufficient phosphorus in the fecd, even though they have ample storage in their bones. This is indicated in the experiment by the following facts: when the animals in Groups III and IV were fed a ration containing as much as or slightly more phosphorus than those in Groups I and II, they maintained the inorganic phosphorus content of their blood. On March 24, 1927, their rations were chang-

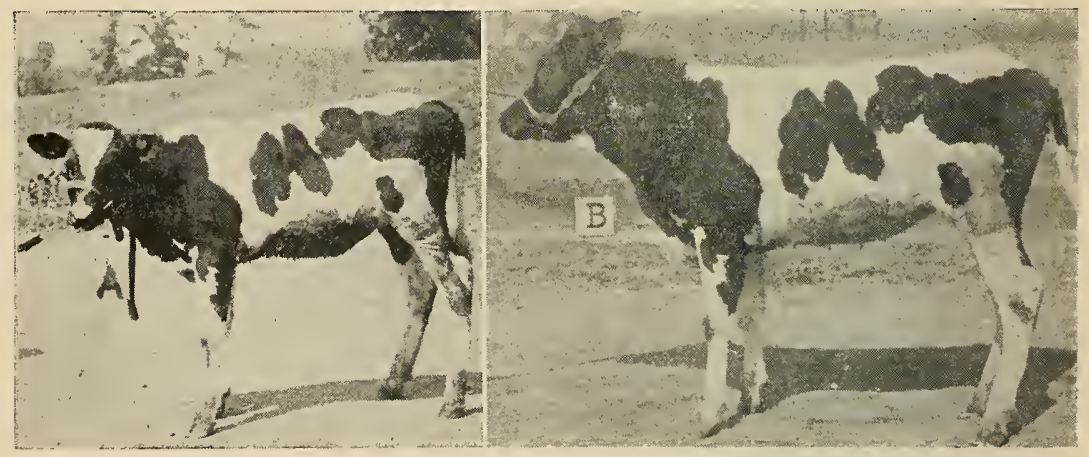

FigURe 7.Number E 20, Showing General Appear. ance at Various Stages of Development. Fed Low-Phosphorus Ration

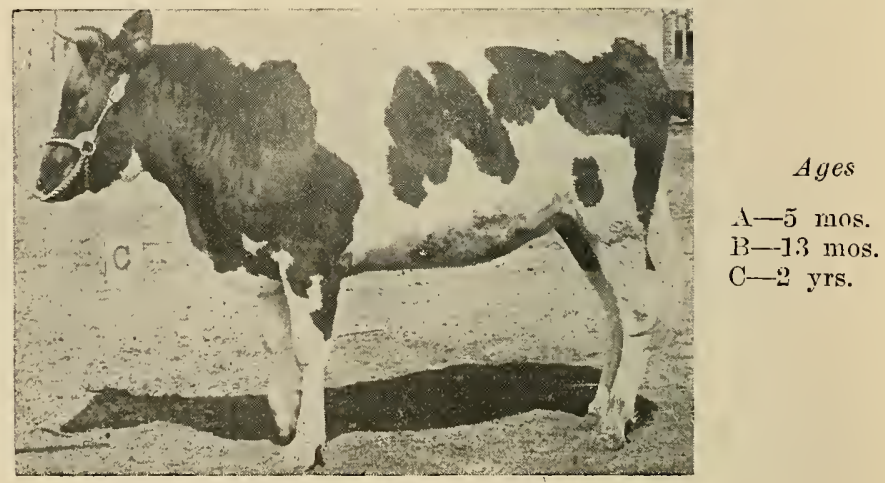


ed from Rations III and [V, which contained 3.4 gms. and 4.1 gms. respectively of phosphorus per hundredweight of the animals, to Rations II I a and I ${ }^{T}$ a, which contained $1.2 \mathrm{gms}$. and $1.4 \mathrm{gms}$. respectively of phosphorus per hundredweight of the animals. Samples of blood were taken beginning March 28, 1927, 4 days after the ration had been changed. In that short period the inorganic phosphorus content of the blood had dropped from an average of $8.15 \mathrm{mg}$. per

Table 11.- Iverage Calcium Content of 100 ic. of Llood of the Animals in the Tarious Groups, by Periods

\begin{tabular}{|c|c|c|c|c|c|}
\hline & \multirow{2}{*}{$\begin{array}{l}\text { Period Ending } \\
\text { When Animals } \\
\text { Were at Age of }\end{array}$} & \multicolumn{4}{|c|}{ Average Calcium Content per $100 \mathrm{cc}$. of Blood } \\
\hline & & Group 1 & Group II & Group III & Group IV \\
\hline $\begin{array}{r}S \\
13 \\
19 \\
25 \\
\end{array}$ & $\begin{array}{l}\text { months } \ldots \ldots \\
\text { months } \ldots \ldots \\
\text { months } \ldots \ldots \\
\text { months }\end{array}$ & $\begin{array}{l}\text { (mgs.) } \\
14.80 \\
14.19 \\
14.62 \\
12.54 \\
\end{array}$ & $\begin{array}{l}(\operatorname{mas.}) \\
14.75 \\
14.72 \\
13.79 \\
13.02 \\
\end{array}$ & $\begin{array}{l}(m g s .) \\
14.80 \\
14.23 \\
14.16 \\
13.17 \\
\end{array}$ & $\begin{array}{l}(m g s .) \\
1.4 .54 \\
14.66 \\
14.73 \\
13.44 \\
\end{array}$ \\
\hline
\end{tabular}

$100 \mathrm{cc}$. of blood to $4.86 \mathrm{mg}$. in the case of Group III, and from 7.93 mg. per $100 \mathrm{cc}$. of blood to $4.35 \mathrm{mg}$. in the case of Group IV. The phosphortis content of the rations was kept at that level, and the inorganic phosphorus in the blood gradually diminished. This would indicate that the animals must depend npon their feed as the source of the inorganic phosphorus of their blood. These animals had had time to store ample phosphorus in their bones which they could have drawn upon in time of need. This, however, they did not seem able to do, depending entirely upon their food for their supply of phosphorus.

As a general rule the concentration of inorganic phosphorus in the blood of normal-fed animals seemed to increase slightly until the animal was about a year old and then to decrease slightly as the animal grew older.

Study of Individuats. No. E 31, which already has been noted as showing signs of conrulsions and bent legs at an early age, showed on her third test the lowest calcium concentration in her blood of any of the animals. Just shortly after this test she developed nervousness, convulsions, and bent legs. On her fourth test the ration had been changed to one containing slightly more calcium and less phosphorus. The concentration of calcium in the blood had increased, but the inorganic phosphorus of the blood then was very low, although the ration had been changed to the low-phosphortis one less than a week previously. This indicates that the concentration of inorganic phosphorus in the blood clianges almost as soon as the phosphorus content of the ration is changed.

No. E 28, which developed a sway in her back together with slightly bent legs, was the lowest of all the heifers during the last 3 tests in the inorganic phosphorts content of her blood. The concentration of inorganic phosphorus seemed to be growing less, and at the time of her death it was only $3.14 \mathrm{mg}$. per $100 \mathrm{cc}$. of blood.

No. E 29, which was fed the same ration as No. E 28, did not show as marked abnormal characteristics as did No. E 28, and her 
blood was not as low in inorganic phosphorus. It, however, was much lower than the blood of the normal animals. Her failure to show marked abnormal characteristics perhaps was due to her individuality, for she was always a strong animal. But she probably would have succumbed later to the effects of the abnormal ration.

The blood of No. E 20, which developed the stiffness in her legs, was low in inorganic phosphorus, but not quite as low as was the blood of No. E 29. It was a little lower than that of her mate, E 21, which did not develop as abnormal characteristics.

This would indicate that the inorganic phosphorus concentration in the blood would be a fairly good index as to whether an animal is receiving sufficient of this element. This apparently is not as true with calcium, although in this particular experiment the amount of calcium in the ration was not reduced to the same extent as it was in the phosphorus rations.

It is difficult to assign a specific value for the normal content of calcium and inorganic phosphorts in the blood of normal animals. Different methods for such determinations have been proposed, many of which do not give concordant results.

Discussion of Results. Meigs, Blatherwick, and Cary (1919) found that with calves the plasma calcium tended to become lower

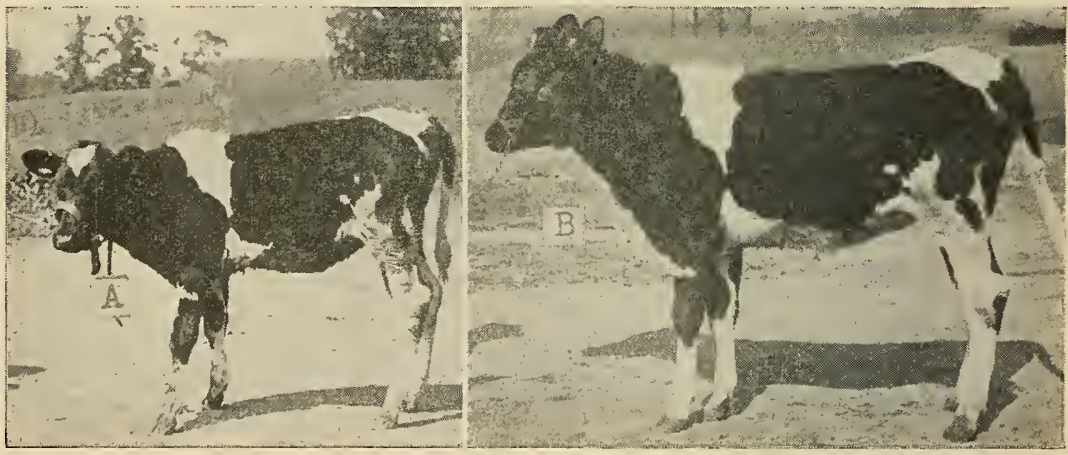

Figure S.--

Number F 21, Showing General Appearance at $\mathrm{Va}$ rious Stages of irevelopment. Fed Low - Phosphorus Ration

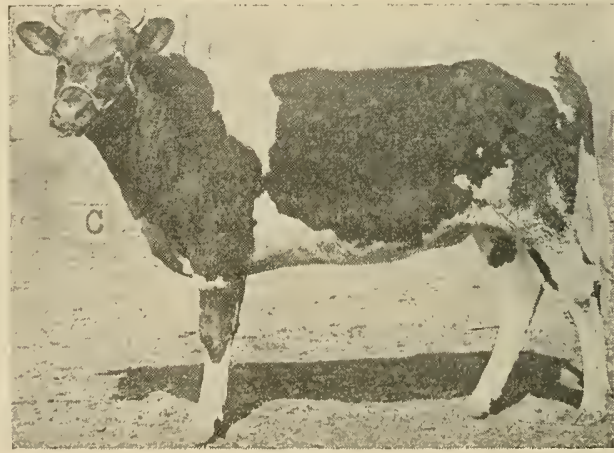

Ages

A-5 mos.

B-13 mos.

C-2 yrs. 
with advancing age up at least to 6 months. The inorganic phosphorus was fairly high at birth but tended to increase until the animal was 6 months of age. Then as a rule it fell off again before the age of 18 months. The calcinm in the serum of normal calves they found to be about $10 \mathrm{mgs}$. per $100 \mathrm{cc}$., with variations from $9.1 \mathrm{mgs}$. to 13.7 mgs. The inorganic phosphorus in the serum was found to average 6.5 to $7 \mathrm{mgs}$. per $100 \mathrm{cc}$., with variations from 5.6 to $9.2 \mathrm{mgs}$.

Meigs was able to reduce the inorganic pinosphorus in the serum by feeding rations low in phosphorus, but was unable to increase to any extent the calcium in the serum by feeding calcium in the ration. His results indicate that in cattle above two months of age the plasma calcium is little, if at all, altered by pregnancy, lactation, or by feeding rations rich in calcium. This was found also by Halverson and co-workers (1917) who found that the calcum content of the serum was little affected by the feeding of calcium in the feed and that it is kept nearly constant by the enormous calcium reserve stored in the bones.

On the other hand, Bethke and co-workers (1923) found that in the absence of normal growth in rats there was a general tendency for a reduced calcium content in the blood and ash content of the bones. The phosphorus content of the blood was found more constant, but apparently as the calcium increased there was a tendency for the phosphorus to be depressed.

TaBLe 12.-Average Phosphoms Content of 100 ic. of Biood of Animals in the Tarious Groups, by Periods

\begin{tabular}{|c|c|c|c|c|c|}
\hline \multirow{2}{*}{\multicolumn{2}{|c|}{$\begin{array}{l}\text { Period Ending } \\
\text { When Animals } \\
\text { Were at Age of }\end{array}$}} & \multicolumn{4}{|c|}{ Arelage Phosphorus Content per 100 cc. of Blood } \\
\hline & & Groul I & Group II & Group III & Group IV \\
\hline $\begin{array}{l}8 \\
13 \\
19 \\
29 \\
\end{array}$ & $\begin{array}{l}\text { months } \ldots \ldots \ldots \\
\text { months } \ldots \ldots \ldots \\
\text { months } \\
\text { months } \ldots \ldots \ldots\end{array}$ & $\begin{array}{c}(m, 1.5) \\
6.63 \\
7.08 \\
6.50 \\
5.98\end{array}$ & $\begin{array}{l}(m a s .) \\
7.41 \\
7.49 \\
7.09 \\
6.31 \\
\end{array}$ & $\begin{array}{l}(m g s .) \\
6.79 \\
8.15 \% \\
4.93 \div \\
4.69\end{array}$ & $\begin{array}{l}(m(1) .) \\
7.37 \\
7.93 * \\
4.057 \\
3.85\end{array}$ \\
\hline
\end{tabular}

* Only one composite was used, since ration lad been changed before the second one was run.

TThree composites were used, since ration had been changed so that they represented the same feeding nethod.

With the experimental animals it was found that the calcium content of the blood varied from 10.29 to $19.95 \mathrm{mgs}$. per $100 \mathrm{cc}$. of the blood. The calcium in the blood was but little affected by the feeding of rations low in this element. This would indicate that the anima! body is able to maintain the concentration of the blood fairly uniform when not receiving sufficient in the ration, by drawing upon the supply stored away. It has already been noted that the animals in Groups II and IV were not receiving sufficient calcium as denoted by their growth and development, but the amount in the blood was at all times ample. This agrees with the results of Meigs and co-workers (1919) and Halverson and co-workers (1917) who found that the concentration of calcium could not be aliered greatly by feeding feeds rich in calcium. 
It was found, however, that the inorganic phosphorus content of the blood could be easily affected by feeding rations low in phosphorus. This would indicate that the animals depend upon their feed to keep up the supply of inorganic phosphorus in their blood.

If 6 mgs. of inorganic phosphorus per $100 \mathrm{cc}$. of blood is considered the minimum concentration of phosphorus consistent with the well-being of an animal, then if less than 2 grams of phosphorus per hundredweight of the animal is fed per day, this concentration will not be maintained. It can be seen that the animals in Group I were fed a ration slightly below this limit. During the last period they consumed only $1.9 \mathrm{gms}$. of phosphorus per hundredweight of the animal in their ration, and the concentration of their blood dropped from 6.50 to $5.98 \mathrm{mgs}$. per $100 \mathrm{cc}$. This ration contained 0.22 percent phosphorus and was therefore considerably less than the optimal ration of at least 0.4146 percent as recommended by McCollum and associates (19.22) for rats.
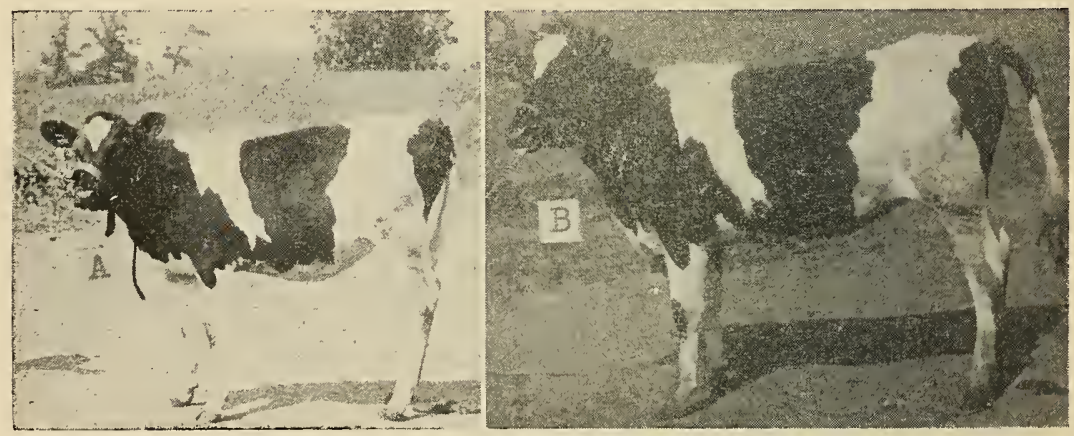

Figure 9. --Number E 2S, Showing Geneial $\Lambda p$ pearance at $\mathrm{V}$ a rious Stages of Development. Fed Low - Calrium - LowPhosphorus Ration

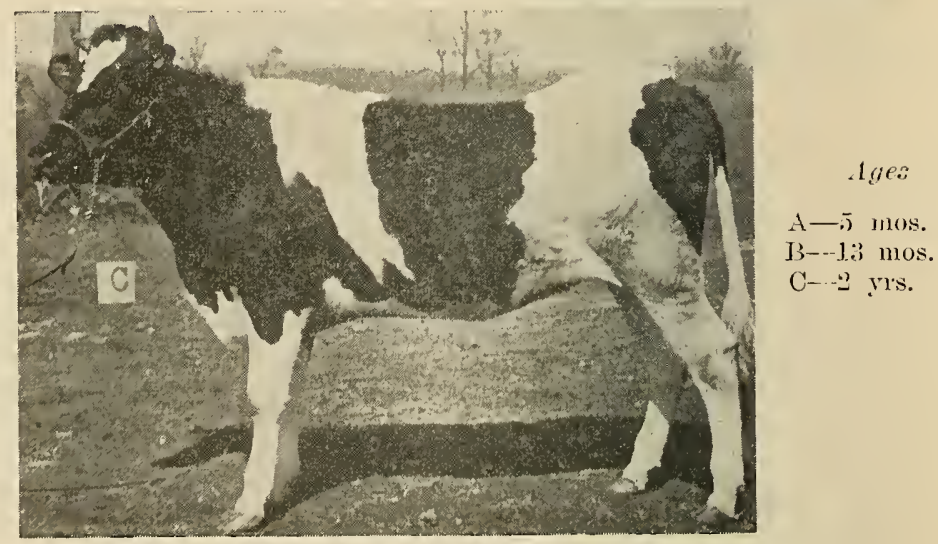




\section{Effect of the Rations upon the Bones of the Animals}

Effect of Composition. Bones are useful in the animal body first, to act as a support and to give shape to the body; second, to protect some of the vital organs; and third, to act as a storehouse for calcium and phosphorus which might be drawn upon later as the animal finds need for it. It would seem reasonable, therefore, that the bones in animals which have been fed rations low in calcium or phosphorus would be lower in total ash than bones of animals fed normal rations.

Therefore, at the time of killing the animals in the experiment, samples were taken of representative bones of the animals. The bones used were the eleventh and twelfth ribs and the femur and humerus from the left side of each animal. Kruger and Bechdel (1925), studying the normal deposition of minerals in the bones of dairy calves, found that the ribs, femurs, and humeri were very suitable for such studies, more so than some other bones which they also studied.

Sampling the Bones. The bones were removed from the carcass very soon after slaughter, scraped free of all adhering flesh, and carefully weighed.

The ribs were sampled by taking pieces about two inches in length from near both ends and from the middle of each. These were carefully weighed and placed in a mason jar which had previously been weighed. They were kept sealed and in a cold room at a temperature of about zero until the time of analysis. The two ribs were then analyzed together.

The femurs and humeri were sampled the first two times by taking a piece $21 / 2$ inches in length from the middle of the shaft of each bone. Upon realizing that this was not a fair sample of the entire bone, this method was changed and during the last two times a longitudinal medial section about $3 / 16$ inch thick was sawed out of each bone.* These were weighed, sealed in a mason jar, and kept in a cold room as were the ribs until the time of analysis. The femurs and humeri were analyzed together. All samples of bones were kept in this manner and analyzed at the same time.

Method of Analysis. At the time of analysis the jars containing the bones were weighed carefully and air-dried at room tempcrature. The bones were then broken up in an iron mortar and the remaining moisture was determined by drying for 48 hours in a vacuum oven maintained at $75^{\circ} \mathrm{C}$. and at a reduced pressure of 27.5 inches of mercury. The dry broken bones were extracted with ether for 24 hours in a large soxhlet, dried, and ground to pass a 20-mesh sieve. Five grams of the ground bone was extracted for 24 hours with ether and then for 36 hours with 95 percent alcohol. The dry-extracted bone was transferred to a platinum dish and ashed in an electric muffle at a low red heat. The ash was dissolved in 4-molar hydrochloric acid.

*Suggested hy Minnesota Agricultural Experiment Station. 
The phosphorus was determined by the official method and the calcium by a slight modification of the McCrudden method. The nonextractable organic matter of the green bone was determined by subtracting the sum of the moisture, extractable material, and ash from 100. It seemed that a better picture of the bone could be obtained if the extractable material, which consists largely of fat and fat-like materials, is not combined with the non-extractable organic materials, as these are usually under the name of organic matter.

Analysis of Ribs. 'Table 13 gives the average percentage of the various constituents in the green bone by periods. This is also expressed in percentages of the normal-fed group.

It will be noted in a study of 'Table 13 that in general the percentage of the ash and the non-extractable organic matter is decreased, and the percentage of water and extractable material is increased in the bones of animals fed rations low in calcium or phosphorus as compared to the bones of normal-fed animals. The percentage of calcium and phosporus in the bones, of course, was decreased as the ash decreased.

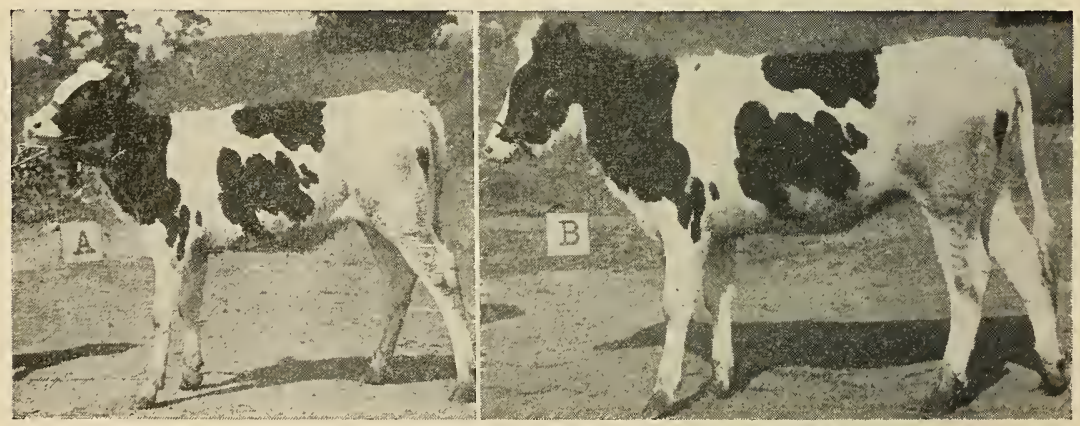

Figure 10.Number E 29 , Showing General Appearance at Varions Stages of Derelopment. Fed Low - Calcium and Low - Phosphorus Ration

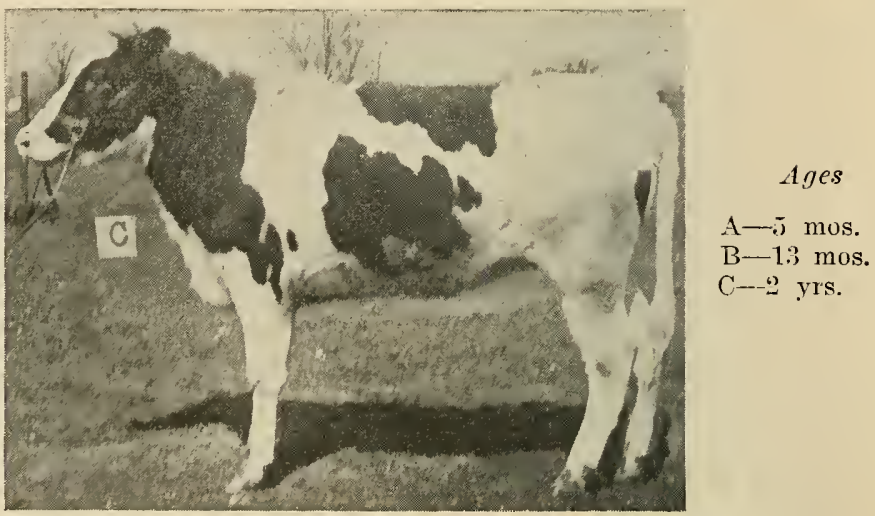


Table 13.-Average Perecntuge of Tarions Constiluerts in Grern Fone (Ribs) of the Various Groups, by Perinds; Expressed also as Pereculuge of the lormal Group

\begin{tabular}{|c|c|c|c|c|c|c|c|}
\hline $\begin{array}{l}\text { Period Find- } \\
\text { ing When } \\
\text { Animals } \\
\text { Were at } \\
\text { Age of }\end{array}$ & 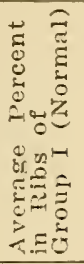 & 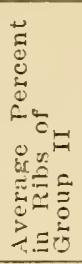 & 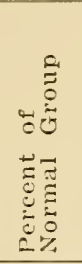 & 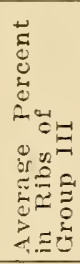 & 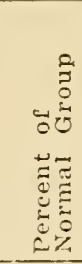 & 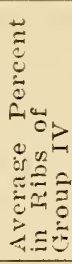 & 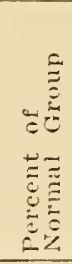 \\
\hline \multicolumn{8}{|c|}{ MOISTURE } \\
\hline $\begin{array}{r}\$ \text { mos. } \\
13 \text { mos. } \\
19 \text { mos. } \\
25 \text { mos. }\end{array}$ & $\begin{array}{l}15.22 \\
18.45 \\
17.33 \\
15.08 \\
\end{array}$ & $\begin{array}{l}16.27 \\
19.57 \\
15.10 \\
15.52\end{array}$ & $\begin{array}{r}106.9 \\
106.1 \\
87.7 \\
102.9\end{array}$ & $\begin{array}{l}14.90 \\
22.70 \\
18.41 \\
17.68\end{array}$ & $\begin{array}{r}97.9 \\
123.0 \\
106.2 \\
117.2 \\
\end{array}$ & $\begin{array}{l}14.71 \\
19.90 \\
18.55 \\
20.93\end{array}$ & $\begin{array}{r}96.7 \\
91.6 \\
107.0 \\
138.7\end{array}$ \\
\hline \multicolumn{8}{|c|}{ EXTRACTABLE MATERIAT } \\
\hline $\begin{aligned} 8 & \text { mos. } \\
13 & \text { mos. } \\
19 & \text { mos. } \\
25 & \text { mos. }\end{aligned}$ & $\begin{array}{r}7.74 \\
9.81 \\
14.21 \\
13.33\end{array}$ & $\begin{array}{r}15.80 \\
8.97 \\
21.11 \\
14.61\end{array}$ & $\begin{array}{r}204.1 \\
91.4 \\
149.2 \\
109.6\end{array}$ & $\begin{array}{r}5.95 \\
10.89 \\
15.32 \\
18.15\end{array}$ & $\begin{array}{r}75.5 \\
111.0 \\
107.7 \\
136.1\end{array}$ & $\begin{array}{l}11.73 \\
11.12 \\
25.16 \\
19.99 \\
\end{array}$ & $\begin{array}{l}151.1 \\
113.3 \\
177.7 \\
150.0 \\
\end{array}$ \\
\hline \multicolumn{8}{|c|}{ NON-EATRACTABLE ORGANIC MATTER } \\
\hline $\begin{aligned} 8 & \text { mos. } \\
13 & \text { mos. } \\
19 & \text { mos. } \\
25 & \text { mos. }\end{aligned}$ & $\begin{array}{l}30.96 \\
27.87 \\
26.13 \\
27.31\end{array}$ & $\begin{array}{l}27.60 \\
29.37 \\
25.15 \\
26.71 \\
\end{array}$ & $\begin{array}{r}89.1 \\
105.4 \\
96.2 \\
97.7\end{array}$ & $\begin{array}{l}31.28 \\
26.12 \\
26.21 \\
25.23\end{array}$ & $\begin{array}{r}101.1 \\
96.5 \\
100.3 \\
92.4\end{array}$ & $\begin{array}{l}29.94 \\
29.82 \\
23.14 \\
26.07\end{array}$ & $\begin{array}{r}96.7 \\
107.0 \\
\text { SS.5 } \\
95.4 \\
\end{array}$ \\
\hline \multicolumn{8}{|c|}{ ASH } \\
\hline $\begin{aligned} 8 & \text { mos. } \\
13 & \text { mos. } \\
19 & \text { mos. } \\
25 & \text { mos. }\end{aligned}$ & $\begin{array}{l}46.08 \\
43.87 \\
42.36 \\
44.27\end{array}$ & $\begin{array}{l}40.31 \\
42.08 \\
38.63 \\
43.15\end{array}$ & $\begin{array}{l}87.5 \\
95.9 \\
91.2 \\
97.1\end{array}$ & $\begin{array}{l}47.96 \\
40.29 \\
10.04 \\
38.93\end{array}$ & $\begin{array}{r}104.1 \\
91.8 \\
94.5 \\
87.9\end{array}$ & $\begin{array}{l}43.56 \\
41.65 \\
33.14 \\
33.01\end{array}$ & $\begin{array}{l}94.5 \\
94.5 \\
78.2 \\
74.5\end{array}$ \\
\hline \multicolumn{8}{|c|}{ CALCILM } \\
\hline $\begin{aligned} 8 & \text { mos. } \\
13 & \text { mos. } \\
19 & \text { mos. } \\
25 & \text { mos. }\end{aligned}$ & $\begin{array}{l}18.25 \\
17.51 \\
16.72 \\
17.68\end{array}$ & $\begin{array}{l}15.87 \\
16.74 \\
15.37 \\
17.20\end{array}$ & $\begin{array}{l}86.9 \\
95.6 \\
91.9 \\
97.3\end{array}$ & $\begin{array}{l}19.07 \\
16.16 \\
16.26 \\
15.68\end{array}$ & $\begin{array}{r}104.5 \\
92.3 \\
97.2 \\
89.7\end{array}$ & $\begin{array}{l}17.20 \\
16.59 \\
13.57 \\
13.42\end{array}$ & $\begin{array}{l}94.2 \\
94.7 \\
81.2 \\
75.8\end{array}$ \\
\hline \multicolumn{8}{|c|}{ PHOSPHORT'S } \\
\hline $\begin{array}{r}8 \text { mos. } \\
13 \text { mos. } \\
19 \text { mos. } \\
25 \text { mos. }\end{array}$ & $\begin{array}{l}8.75 \\
8.25 \\
7.96 \\
8.21\end{array}$ & $\begin{array}{l}7.70 \\
7.97 \\
7.25 \\
8.05 \\
\end{array}$ & $\begin{array}{l}88.0 \\
86.9 \\
91.6 \\
98.0 \\
\end{array}$ & $\begin{array}{l}9.08 \\
7.60 \\
7.42 \\
7.23\end{array}$ & $\begin{array}{r}103.8 \\
92.1 \\
93.2 \\
88.1 \\
\end{array}$ & $\begin{array}{l}8.26 \\
7.90 \\
6.25 \\
6.09\end{array}$ & $\begin{array}{l}94.4 \\
96.1 \\
78.5 \\
74.2\end{array}$ \\
\hline
\end{tabular}

Extractable material and water seem to replace the ash and to a certain extent the non-extractable organic matter in the bones as the animal is deprived of normal rations. In the case of the animals in Group IV, which were fed a ration low in both calcium and phosphorus, at the end of the experiment the amount of ash and of calcium and phosphorus in the ribs was only about three-fourtins of the amount in the bones of the normal-fed animals.

In Table 14 the average ash of the dry-extracted ribs and also the arerage percentage of calcinm and phosphorus in the ash are given by periods and groups.

Table 14 shows that as the ration is limited in calcium and phosphorus, the amount of ash in the dry-extracted bone also is lowered in a very sinilar way as it is with the green bone. but since the water and extractable material had been remored the results were not as pronounced. The amount of calcium and phosphorus in the ash is affected but little by the ration fed. 
Analysis of Femur and Humerus. Table 15 shows the average analysis of the various constituents of the bones for the different groups by periods.

The same general results were obtained by these analyses as by analyses of the ribs. Very little effect was shown at first when the ration was not reduced, but as soon as the rations were reduced there was an immediate effect upon the composition of the bones. This, in general, was a reduction in the ash and non-extractable organic matter and an increase in water and extractable material. The calcium and phosphorus also were reduced as the ash was reduced. The bones of the low-mineral-fed groups were affected, but the effects were more pronounced as to their calcium and phosphorus content.

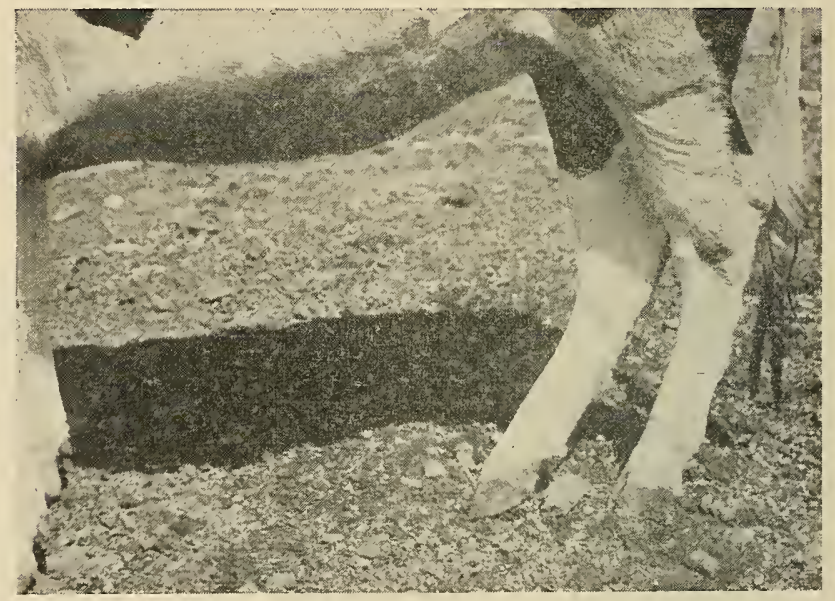

Frgure 11.--Showing the Legs of E 20. Note That They Are Slightly Bent. Taken at Time of Killing

There was an indication that the shaft of the bone is more stable in its composition than the ends of the bone. The bones of the lowmineral-fed groups during the first two periods when the samples were taken from the center of the bone wcre as high and in most cases higher in ash content and in their content of calcium and phosphortus than were the bones of the normal-fed group, while the ribs during the corresponding period showed some effect of the decreased mineral supply. When, however, the sampling was changed to include the entire length of the bone, the effect was just as pronounced with the femurs and humeri as with the ribs. This is as might be expected, however, since the growing parts of the bones are at the ends and these naturally would be the first affected.

The average amount of ash in the dry-extracted femur and humerus and the amount of calcium and phosphorus in the ash of the individual animals, averaged for groups by periods, is given in 'Table 16.

Table 16 shows again that in the dry-extracted bones the amount 36 
TABLE 14.- A verage Perecntage of Ash in Dry-Extracted. Ribs, and Average Pereentage of Calcium and I'hosphorts in Ash of Ribs, Given as the Average of All Groups by Periods; Expressed also as Iereentage of the Normal Group

\begin{tabular}{|c|c|c|c|c|c|c|c|}
\hline $\begin{array}{l}\text { Period Find- } \\
\text { ing When } \\
\text { Inimals } \\
\text { Were at } \\
\text { Age of }\end{array}$ & 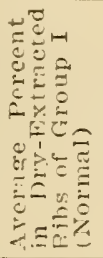 & 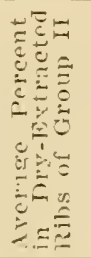 & 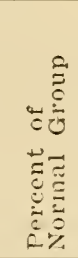 & 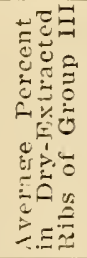 & 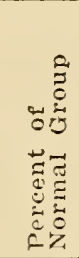 & 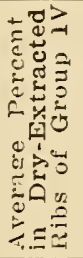 & 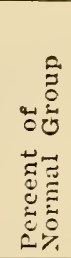 \\
\hline \multicolumn{8}{|c|}{ ASII (DPF-EXTRACTED) } \\
\hline $\begin{aligned} 8 & \text { mos. } \\
13 & \text { mos. } \\
19 & \text { mos. } \\
25 & \text { mos. }\end{aligned}$ & $\begin{array}{l}69.86 \\
61.15 \\
61.86 \\
61.89 \\
\end{array}$ & $\begin{array}{l}5 ! .35 \\
58.58 \\
60.57 \\
61.70\end{array}$ & $\begin{array}{l}99.1 \\
96.2 \\
95.7 \\
99.3 \\
\end{array}$ & $\begin{array}{l}59.80 \\
59.92 \\
60.44 \\
60.67\end{array}$ & $\begin{array}{l}99.9 \\
98.0 \\
9 \$ .5 \\
98.0 \\
\end{array}$ & $\begin{array}{l}59.16 \\
57.93 \\
58.83 \\
55.74 \\
\end{array}$ & $\begin{array}{l}98.8 \\
94.7 \\
95.8 \\
90.0 \\
\end{array}$ \\
\hline \multicolumn{8}{|c|}{ CALCIEXI IN THE ASH } \\
\hline $\begin{aligned} 8 & \text { nos. } \\
13 & \text { mos. } \\
19 & \text { mos. } \\
25 & \text { mos. }\end{aligned}$ & $\begin{array}{l}39.61 \\
39.91 \\
40.03 \\
39.93 \\
\end{array}$ & $\begin{array}{l}39.56 \\
39.79 \\
39.80 \\
39.87\end{array}$ & $\begin{array}{l}99.3 \\
99.7 \\
99.4 \\
99.8 \\
\end{array}$ & $\begin{array}{l}39.77 \\
40.72 \\
40.60 \\
40.25\end{array}$ & $\begin{array}{l}100.4 \\
100.5 \\
101.4 \\
100.5\end{array}$ & $\begin{array}{l}39.4 \mathrm{~S} \\
39.93 \\
40.96 \\
40.64 \\
\end{array}$ & $\begin{array}{r}99.4 \\
99.8 \\
102.3 \\
101.8 \\
\end{array}$ \\
\hline \multicolumn{8}{|c|}{ PHOSPHORLS IN THE ASH } \\
\hline $\begin{array}{r}8 \text { mos. } \\
13 \text { mos. } \\
19 \text { mos. } \\
25 \text { mos. }\end{array}$ & $\begin{array}{l}19.98 \\
18.91 \\
18.80 \\
18.56 \\
\end{array}$ & $\begin{array}{l}19.09 \\
18.94 \\
18.87 \\
18.61 \\
\end{array}$ & $\begin{array}{l}100.5 \\
100.1 \\
100.3 \\
100.3 \\
\end{array}$ & $\begin{array}{l}18.97 \\
18.88 \\
18.53 \\
18.55\end{array}$ & $\begin{array}{r}100.0 \\
99.8 \\
98.5 \\
100.0 \\
\end{array}$ & $\begin{array}{l}18.96 \\
18.97 \\
18.56 \\
18.45 \\
\end{array}$ & $\begin{array}{r}99.9 \\
100.3 \\
98.7 \\
99.4\end{array}$ \\
\hline
\end{tabular}

of ash is lessened by feeding rations restricted in calcium or phospliorus. The same general results were obtained as with the green bones but the differences were not as pronounced. The composition of the ash is affected but little in regard to its calcium and phosphorus content.

Discussion of Results. The results of the analyses of the ribs and of the fentur and humerts of the varions animals in a general way are similar, except for the different methods of sampling used during the first two periods with the femur and humerus. As a rule, when the analyses of the ribs varied from normal, the analyses of the femur and hunnerus of the sanne group would vary in like manner. This would indicate that either type of bone conld be used equally well in studying the effects of rations low in calcium or phosphorus upon the bones of animals. Both indicated that rations low in one or both minerals, but normal in regard to digestible protein and digestible nutrients, when fed to growing dairy animals, bring about a change in the composition of the bones of such animals. Such a change is characterized by an increase in the water and extractable material in the bone and by a corresponding decrease of the ash and nonextractable organic matter. The amount of calcium and phosphorus of the green bone also was decreased. The dry-extracted bone also shows less ash when such rations are fed, but not to the same extent as in the green bone. As far as the ash was concerned it contained practically the same percentage of calcium and phosphorus as did the bones of calves on normal rations.

It will be noted that the bones of the animals in the normal-fed group maintained fairly uniform composition at the different ages 
TABle 15.-Average Percentage of Various Constituents of Green Bone (Femur and Humerus) in the Various Groups, by Periods; Expressed also as Percentage of the Normal Group *

\begin{tabular}{|c|c|c|c|c|c|c|c|}
\hline $\begin{array}{c}\text { Period End- } \\
\text { ing When } \\
\text { Animals } \\
\text { Were at } \\
\text { Age of }\end{array}$ & 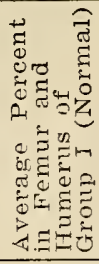 & 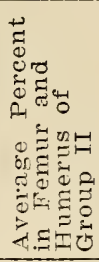 & 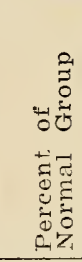 & 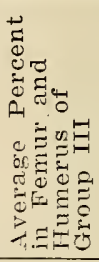 & 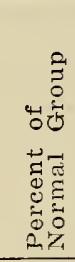 & 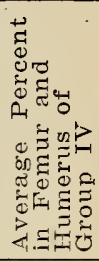 & 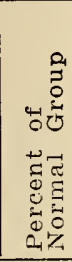 \\
\hline \multicolumn{8}{|c|}{ MOISTURE } \\
\hline $\begin{aligned} & 8 \text { mos. } \\
& 13 \text { mos. } \\
& 19 \text { mos. } \\
& 25 \text { mos. } \\
&\end{aligned}$ & $\begin{array}{l}11.65 \\
13.50 \\
17.35 \\
13.64 \\
\end{array}$ & $\begin{array}{r}9.32 \\
13.26 \\
17.92 \\
15.55 \\
\end{array}$ & $\begin{array}{r}80.0 \\
98.2 \\
103.3 \\
113.6 \\
\end{array}$ & $\begin{array}{l}10.76 \\
14.14 \\
16.45 \\
15.94 \\
\end{array}$ & $\begin{array}{r}92.4 \\
95.3 \\
105.2 \\
116.9 \\
\end{array}$ & $\begin{array}{l}11.50 \\
14.66 \\
17.68 \\
19.90 \\
\end{array}$ & $\begin{array}{r}98.7 \\
108.6 \\
101.9 \\
145.9 \\
\end{array}$ \\
\hline \multicolumn{8}{|c|}{ EXTRACTABLE MATERIAI, } \\
\hline $\begin{aligned} 8 & \text { mos. } \\
13 & \text { mos. } \\
19 & \text { mos. } \\
25 & \text { mos. }\end{aligned}$ & $\begin{array}{r}3.27 \\
1.81 \\
28.73 \\
31.60\end{array}$ & $\begin{array}{r}4.77 \\
0.60 \\
29.40 \\
30.68 \\
\end{array}$ & $\begin{array}{r}145.9 \\
33.1 \\
102.3 \\
97.7 \\
\end{array}$ & $\begin{array}{r}4.88 \\
0.51 \\
29.49 \\
34.16\end{array}$ & $\begin{array}{r}149.2 \\
28.2 \\
102.6 \\
108.1\end{array}$ & $\begin{array}{r}1.50 \\
0.89 \\
36.69 \\
39.40 \\
\end{array}$ & $\begin{array}{r}45.8 \\
49.2 \\
127.7 \\
124.3\end{array}$ \\
\hline \multicolumn{8}{|c|}{ NON-EXTRACTAHIE ORGANIC MATTER } \\
\hline $\begin{aligned} 8 & \text { mos. } \\
13 & \text { mos. } \\
19 & \text { mos. } \\
25 & \text { mos. }\end{aligned}$ & $\begin{array}{l}26.72 \\
27.91 \\
19.21 \\
19.04 \\
\end{array}$ & $\begin{array}{l}25.57 \\
27.08 \\
20.10 \\
20.19 \\
\end{array}$ & $\begin{array}{r}95.6 \\
97.0 \\
104.7 \\
102.8 \\
\end{array}$ & $\begin{array}{l}25.35 \\
27.19 \\
19.39 \\
18.29\end{array}$ & $\begin{array}{r}94.4 \\
57.4 \\
100.9 \\
52.6 \\
\end{array}$ & $\begin{array}{l}26.30 \\
26.65 \\
16.47 \\
17.94 \\
\end{array}$ & $\begin{array}{l}98.4 \\
95.5 \\
85.7 \\
86.3 \\
\end{array}$ \\
\hline \multicolumn{8}{|c|}{ ASH } \\
\hline 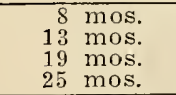 & $\begin{array}{l}58.34 \\
58.27 \\
34.70 \\
35.06\end{array}$ & $\begin{array}{l}60.33 \\
60.06 \\
32.58 \\
33.08 \\
\end{array}$ & $\begin{array}{r}103.4 \\
103.1 \\
93.8 \\
94.3 \\
\end{array}$ & $\begin{array}{l}58.91 \\
58.61 \\
3+.66 \\
31.60 \\
\end{array}$ & $\begin{array}{r}100.9 \\
100.6 \\
99.8 \\
90.1 \\
\end{array}$ & $\begin{array}{l}60.70 \\
57.84 \\
29.12 \\
22.75\end{array}$ & $\begin{array}{r}102.3 \\
99.2 \\
83.9 \\
64.8\end{array}$ \\
\hline \multicolumn{8}{|c|}{ CALCIUM } \\
\hline 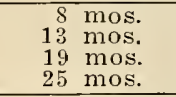 & $\begin{array}{l}23.13 \\
23.03 \\
13.83 \\
13.89 \\
\end{array}$ & $\begin{array}{l}23.88 \\
23.84 \\
19.97 \\
13.13 \\
\end{array}$ & $\begin{array}{r}103.2 \\
103.5 \\
93.8 \\
94.5 \\
\end{array}$ & $\begin{array}{l}23.40 \\
23.40 \\
13.85 \\
12.04 \\
\end{array}$ & $\begin{array}{r}101.1 \\
101.1 \\
100.1 \\
91.0\end{array}$ & $\begin{array}{r}24.03 \\
23.06 \\
11.81 \\
9.14\end{array}$ & $\begin{array}{r}103.8 \\
100.1 \\
85.4 \\
65.8\end{array}$ \\
\hline \multicolumn{8}{|c|}{ PHOSPHORUS } \\
\hline $\begin{aligned} 8 & \text { mos. } \\
13 & \text { mos. } \\
19 & \text { mos. } \\
25 & \text { nos. }\end{aligned}$ & $\begin{array}{r}10.89 \\
10.91 \\
6.45 \\
6.61\end{array}$ & $\begin{array}{r}11.23 \\
10.79 \\
6.15 \\
6.41\end{array}$ & $\begin{array}{r}103.1 \\
98.9 \\
95.3 \\
96.9\end{array}$ & $\begin{array}{r}10.10 \\
11.00 \\
6.44 \\
5.94\end{array}$ & $\begin{array}{r}92.7 \\
100.8 \\
99.9 \\
89.8\end{array}$ & $\begin{array}{r}11.30 \\
10.91 \\
5.39 \\
4.28\end{array}$ & $\begin{array}{r}103.7 \\
100.0 \\
82.9 \\
64.7\end{array}$ \\
\hline
\end{tabular}

during the entire experiment. There were slight variations from one period to another but the differences were not great.

The bones of the animals in Group II, which was fed a ration low in calcium throughout the experiment, slowed the typical variation in composition. In general, from the first they were high in moisture and in extractable material and low in non-extractable organic matter and in ash. The ash seemed to increase toward the latter part of the experiment. This checks with observation, since the animals in this group seemed to improve in general appearance and thrift toward the end of the experiment. They, however, were fed the same ration at all times. The only explanation for this is that the requirements for calcium were lowered as the animals approached maturity and were not growing so fast as previously, and that, while the ration was not sufficient when the animals were younger and growing fast, it was sufficient when this period of rapid growth was

*It must be borne in mind in studying Table 15 that the first two analyses given in the table cannot be compared directly with the last two analysies, since different methods of sampling were used. 'The first two and the last two can be compared, and in a general way all four can be considered together. 
over. At any rate, the bones of the animals in this group from the analyses seemed to be approaching normal toward the end of the experiment.

The bones of the animals in Group III, the low-phosphorus group, after the first period, when their ration approxinated normal, showed the same general composition as the low-calcium group. The ash and non-extractable organic matter was found decreased while the water and extractable material was increased. Here, again, the composition of the bones correlated with the general appearance of the animals. Individuals in this group, as was seen, had developed abnormal characteristics during the last period, and the analyses show that the bones of this group at the last killing contained over 10 percent less ash than those of normal-fed animals.

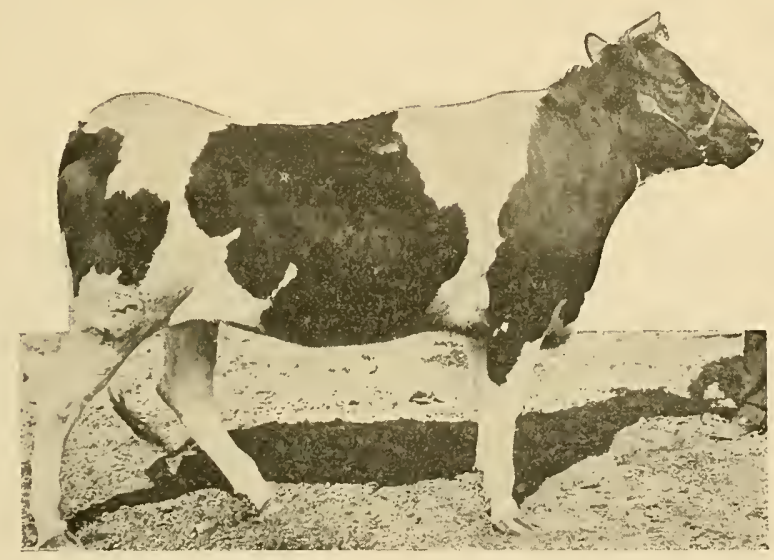

Figlite 12.- Showing E 28. Note the Sway in Her Back. Taken at Time of Killing

The bones of the animals in Group IV showed the greatest difference in their composition. This group was fed a ration low in both phosphorus and calcium. The ration, however, was not low in phosphorus until almost the time of the second killing; consequently during the first two periods the bones should compare with those in Group II. The analyses show a fair degree of comparison between the two groups. During the last two periods the ration of Group IV was very low in phosphorus and consequently its bones were much reduced in ash. The ribs contained scarcely 75 percent and the femur and humerus scarcely 65 percent as much ash as the normal bone at the time of the final killing. The animals in this group at that time were growing slowly and had developed abnormal characteristics, shown by the sway in the back of individual animals. The bones of these animals contained more moisture and were very much higher in the amount of extractable material than the bones of normal-fed animals.

The results found in this study were very similar to those obtained by other investigators, since many have found that the ash content 
TABLE 16.-Average Percentage of Ash in Dry-Extracted Femurs and Humeri, and Average Percentage of Calcium and Phosphorus in Ash, Given as the Average of All Groups, by Periods; Expressed also as Percentage of the Normal Group

\begin{tabular}{|c|c|c|c|c|c|c|c|}
\hline $\begin{array}{c}\text { Period End- } \\
\text { ing When } \\
\text { Animals } \\
\text { Were at } \\
\text { Age of }\end{array}$ & 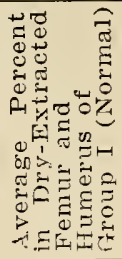 & 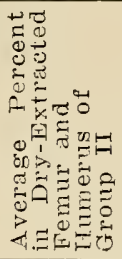 & 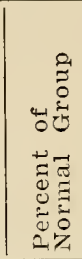 & 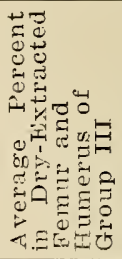 & 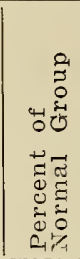 & 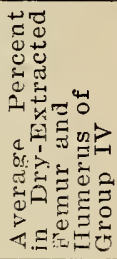 & 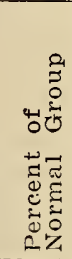 \\
\hline \multicolumn{8}{|c|}{ ASH } \\
\hline 8 mos. & 69.24 & 70.25 & 301.4 & 70.13 & 101.3 & 69.76 & 100.7 \\
\hline & 68.79 & 69.72 & 101.3 & 68.67 & 99.8 & 69.49 & 101.0 \\
\hline 19 mos. & 64.36 & 61.85 & 96.2 & 64.13 & 99.6 & 51.75 & 95.9 \\
\hline 25 mos. & 64.08 & 62.95 & 98.2 & 63.15 & 98.5 & 57.09 & 89.1 \\
\hline \multicolumn{8}{|c|}{ CALCIUM } \\
\hline 8 mos. & 39.65 & 39.58 & $\therefore 9.8$ & 39.72 & 100.2 & 39.58 & 99.8 \\
\hline 13 mos. & 39.53 & 39.70 & 100.4 & 39.92 & 100.9 & 39.87 & $100 . \mathrm{s}$ \\
\hline 19 mos. & 39.86 & 39.82 & 99.9 & 39.96 & 100.2 & 40.54 & 101.7 \\
\hline 25 mos. & 39.63 & $39.6 \mathrm{~s}$ & 100.1 & 39.99 & 100.8 & 40.19 & 101.4 \\
\hline \multicolumn{8}{|c|}{ PHOSPHORUS } \\
\hline 8 mos. & 18.62 & 18.61 & 100.0 & 17.12 & 91.9 & 18.63 & 100.0 \\
\hline $\begin{array}{l}13 \text { mos. } \\
19 \text { mos. }\end{array}$ & $\begin{array}{l}18.73 \\
18.75\end{array}$ & $\begin{array}{l}18.79 \\
18.88\end{array}$ & $\begin{array}{l}100.3 \\
100.7\end{array}$ & $\begin{array}{l}18.76 \\
18.57\end{array}$ & $\begin{array}{r}100.1 \\
99.0\end{array}$ & $\begin{array}{l}18.87 \\
18.50\end{array}$ & $\begin{array}{r}1110.7 \\
98.6\end{array}$ \\
\hline 25 mos. & 18.85 & 19.10 & 101.3 & 18.81 & 99.8 & 18.84 & 100.0 \\
\hline
\end{tabular}

of bones is lowered when animals are fed rations low in minerals. Voit (1880) found that the skeleton of pigeons and of puppies became weakened and porous on rations low 11 calcium. He described the condition as rachitic. Weiske and Wildt (18\%3) found that with lambs fed rations low in calcium and phosphorus, the ratio of the two minerals in the compact part of the bone remained the same as in the normal bone but that the percentage of calcium and phosphorus was reduced.

Maynard, Goldberg, and Miller (1925) found that the bones of stiff pigs, fed a calcium-deficient diet, were markedly lower in dry matter, ash, calcium, and phosphorus than litter mates which received adequate rations. Increasing the amount of calcium in the basal ration by adding bonemeal or limestone produced bones much higher in calcium and phosphorus and saved the animal from stiffness. There was a striking tendency for the calcium and phosphorus ratio to remain constant in the bone ash.

Hart, McCollum, and Fuller (1909) found that on rations extremely low in phosphorus the percentage of ash in the skeleton of pigs was reduced to nearly one-half that of pigs receiving normal rations. They also found that the calcium and phosphorus tended to remain in the same proportion as in the normal pig. This indicates that when an animal is starved for phosphorus it draws this element from the skeleton but removes calcium and phosphorus in the proportion found in tri-calcium phosphate.

In studies of bone growth Hammett $(1925,1925 a, 19256)$ found that the humerus and femur decreased in water content and increased in ash content as the animal grew older. The organic matter con- 
tinued about the same. The calcium in the bones increased as the animal grew older and the phosphorus and magnesium percentage decreased. The change in the composition was practically complete at 75 days of age, the end of puberal period.

Kruger and Bechdei (19:S) experimenting with dairy calves under 6 months of age found that the percentage of phosphorus and calcium in the bone ash is nearly constant and varies only slightly with the age of the animal. The percentage of water decreases, while the percentage of ash and organic matter increases with the age of the animals. The ash replaces the greater part of the decrease in the water percentage.

Effect on Appearance. Figures 13 and 14 show the appearance of the femurs of animals from each group at the time of the last killing.

The appearance of the femurs and humcri of the different groups at that time were quite noticeably different.

The femurs and humeri of the animals in the normal group were dense at the end and hard in the shaft. The walls of the shaft were thick and the amount of marrow was only 8.2 percent of the weight of the bone. The entire bone was well calcified.

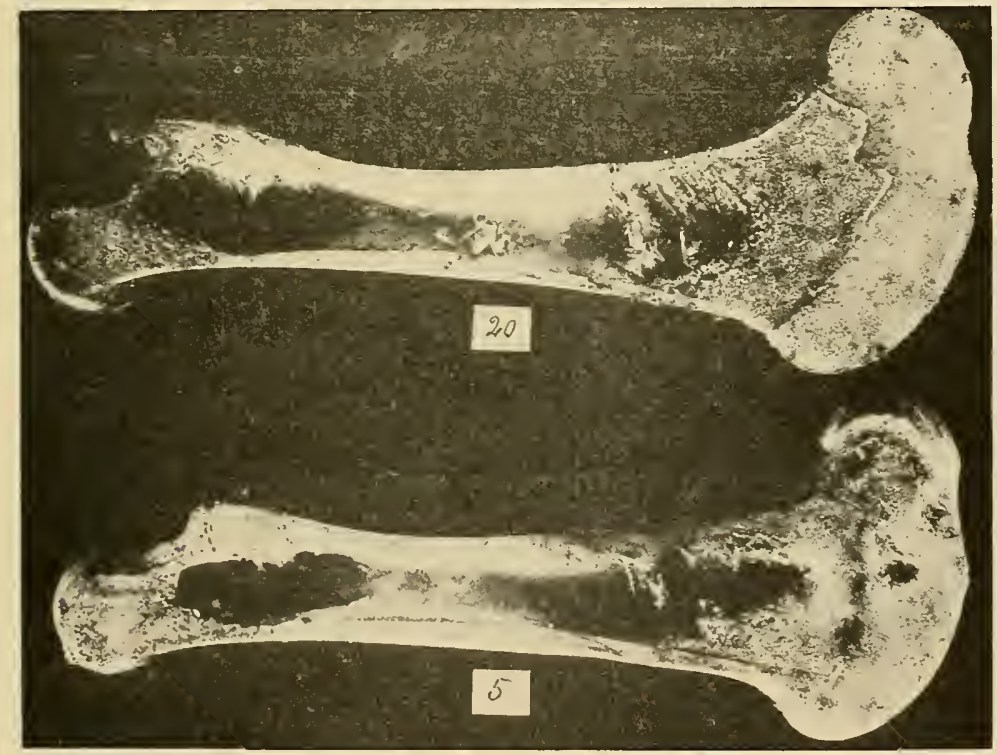

FIgURE 13.-Cross-section of Femur of Animals E 5, from the Normal Group, and E 20, from the Low-Phosphorus Group

The femurs and humeri of the animals in Group IV, the lowcalcium-low-phosphorus group, were spongy and soft at the ends. The shaft while hard was not as thick as the norm.l bone. and there was a larger amount of narrow. Upon weighing it was found that 10.3 percent of the weight of the bone was marrow. The ends of the bones were not well calcified but took of the nature of a rachitic 
bone as described by McCollum and Simmonds (1927). They state that "in the rachitic bone all the processes of growth and the maintenance of equilibrium are abnormal. Calcium salts are not deposited in the normal way. In a normal bone the junction of the cartilage with the shaft forms a straight regular line. In the rachitic bone it is ragged because there is no provisional zone of calcification and the cartilage is invaded by large tufts of blood vessels from the shaft which destroy it irregularly. At the same time masses of cartilage persist where they should be destroyed, and islands remain cut off from the main body of the tissue. Osteoid is not calcified, as it is formed either in the trabeculae or by the periosteum, so that the bone becomes soft. The animal attempts unsuccessfully to compensate for the weakness due to the lack of lime salts by producing osteoid tissue in abnormal amounts, especially at points subject to stress and strain. ... This overproduction of osteoid and cartilage causes irregular enlargements of the bones, and their weakness consequent upon the lack of lime salts results in bowing and fracture."

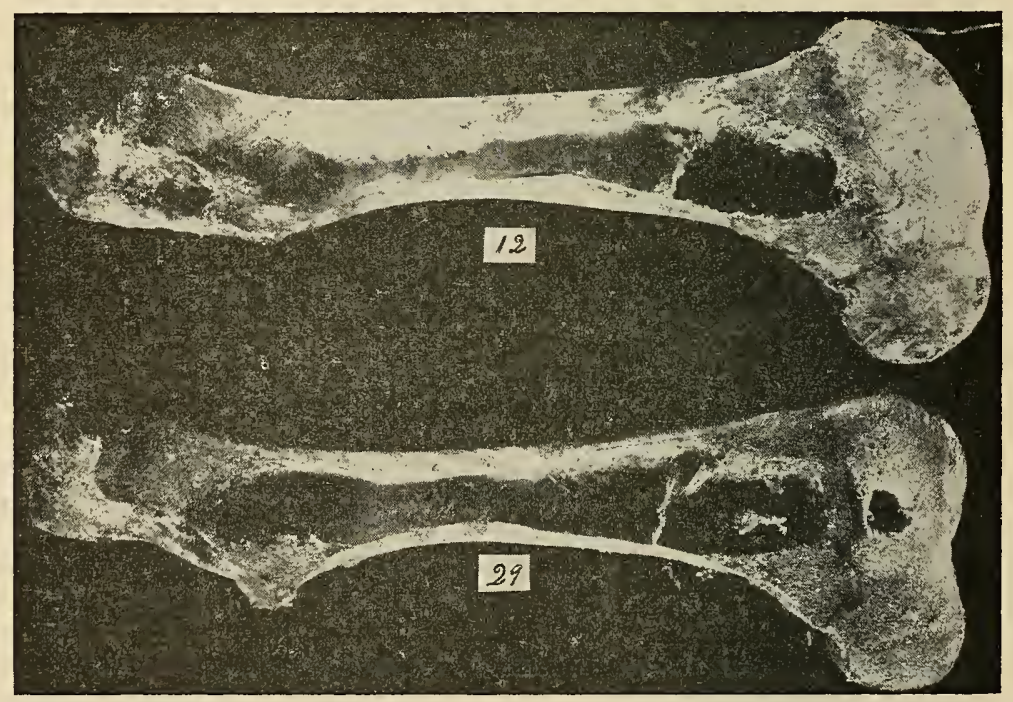

Frgure 14.-Cross-section of Femur of Animals E 12, from the Low-calcium Group, and $\mathrm{E} 29$, from the Low-calcium-low-phosphorus Group

When these bones were allowed to remain for a few days in a room of ordinary temperature, they became dark in color and expelled a considerable amount of moisture. After allowing the tarsal bones to remain for several days in this manner, it was found that the shaft had split longitudinally at two or three places and had expelled a large amount of moisture.

The femurs and humeri of the bones in Group II, the low-calcium group, were very similar to those of Group IV. They were soft and spongy at the ends but in this respect were not so bad as were those 
of Group IV. The shaft was dense but the walls were thin. It was found that 10.4 percent of the weight of the bone was narrow. The bones upon standing slowed the same general characteristics as those of Group IV.

TABLE 17.-Average Brealing Strength of Tarsal Bone of Animals in the Farious Groups

\begin{tabular}{|c|c|c|c|c|c|c|c|c|}
\hline \multirow{2}{*}{ Item } & \multicolumn{2}{|c|}{ Group I } & \multicolumn{2}{|c|}{ Group II } & \multicolumn{2}{|c|}{ Group III } & \multicolumn{2}{|c|}{ Group IV } \\
\hline & $19 \mathrm{mo}$. & $25 \mathrm{mo}$. & $19 \mathrm{mo}$. & $25 \mathrm{mo}$. & $19 \mathrm{mo}$ & $25 \mathrm{mo}$ & $19 \mathrm{mo}$ & $25 \mathrm{mo}$. \\
\hline $\begin{array}{l}\text { Average weight of } \\
\text { animals (pounds) }\end{array}$ & 764 & 966 & 688 & 833 & 721 & 924 & 645 & 782 \\
\hline $\begin{array}{l}\text { Breaking strength of } \\
\text { bones (pounds) }\end{array}$ & 1135 & 2020 & 942 & 1490 & 1165 & 2030 & 915 & 1010 \\
\hline $\begin{array}{l}\text { Breaking strength of } \\
\text { bones per cwt. of } \\
\text { aninial (pounds) }\end{array}$ & 148.5 & 209.1 & 136.9 & 178.9 & 161.6 & 218.5 & 141.8 & 129.1 \\
\hline $\begin{array}{l}\text { Average breaking } \\
\text { strength (pounds) }\end{array}$ & \multirow{2}{*}{\multicolumn{2}{|c|}{1572}} & \multicolumn{2}{|c|}{1261} & \multicolumn{2}{|c|}{1597} & \multicolumn{2}{|c|}{962} \\
\hline $\begin{array}{l}\text { Average breaking } \\
\text { strength per cwt. of }\end{array}$ & & & \multirow{3}{*}{\multicolumn{2}{|c|}{$\begin{array}{r}157.9 \\
89.4\end{array}$}} & \multirow{3}{*}{\multicolumn{2}{|c|}{$\begin{array}{l}190.0 \\
106.2\end{array}$}} & \multirow{3}{*}{\multicolumn{2}{|c|}{$\begin{array}{r}135.4 \\
75.7 \\
\end{array}$}} \\
\hline inimal (pounds) ... & \multicolumn{2}{|c|}{178.8} & & & & & & \\
\hline Percent of normal gr & & 00.0 & & & & & & \\
\hline
\end{tabular}

The femurs and humeri of the animals in Group III, those fed the low-phosphorus ration, were somewhat different from the ones already described. While the ends of the bones were soft and spongy and not well calcified, the center of the bone was hard and the walls were as thick as those of the animals in the normal group. The amount of marrow also was about the same as in the normal bones, as 8.3 percent of the bone was marrow. These bones seemed to be affected more at the ends than in the shaft.

At time of slaughter it was found that there was a slight enlargement at the costochondral junction of the ribs of the animals in Groups II and IV. These could not be described as "beads," but at the point of junction there were enlargements surrounding the junction which seemed to consist largely of fat or fat-like material. This is shown in Figure 15 for the animal E 28. The ribs of these two Groups, especially the twelfth, were not well calcified and upon standing turned dark and emitted moisture. In the case of the animals in group IV it was found that the twelfth rib was composed largely of cartilage. This was not shown as pronounced in the animals of the other groups.

Effect of Breaking Strength. The breaking strength was determined of the tarsal bone taken from the left leg of the animals at the ages of 19 months and 25 months. These were all determined at the same time after the first set of bones had dried out for some time. The two therefore are not strictly comparable.

Since the animals were not all of the same size the breaking strength of the bones was calculated per hundredweight of the animal. The results are given in Table 17 .

It will be noted that whereas the breaking point of the bones of Groups II and IV was below that of the normal-fed group, that of Group III was above. 
The breaking strength of the bones was taken on the shaft. The bones of the animals in Group III, as shown by a study of their composition, were affected just as much or even slightly more than were those of the animals in Group II, but only ends of the bones were affected. The shaft of the bones was just as thick as shown by measurements, by breaking strength, and by the amount of marrow, as was the shaft of the bones of the animals fed normal rations. This would seem to substantiate the indication already mentioned that, while the animal has the power to draw upon the storage of calcium in the bone in order to maintain the normal amount in the blood, it does not have the power to draw upon the reserve of phosphorus sufficiently to keep the inorganic phosphorus of the blood normal.

The breaking strength of the bones of the animals in Group II, the low-calcium group, was only 89.4 percent, and that in Group IV, the low-calcium-low-phosphorus group, was only 75.7 percent of the breaking strength in the normal-fed group.

Summary. Feeding rations to growing dairy animals which are low in calcium or phosphorus or in both these minerals results in changes in the bones as shown by analysis, breaking strength, and appearance.

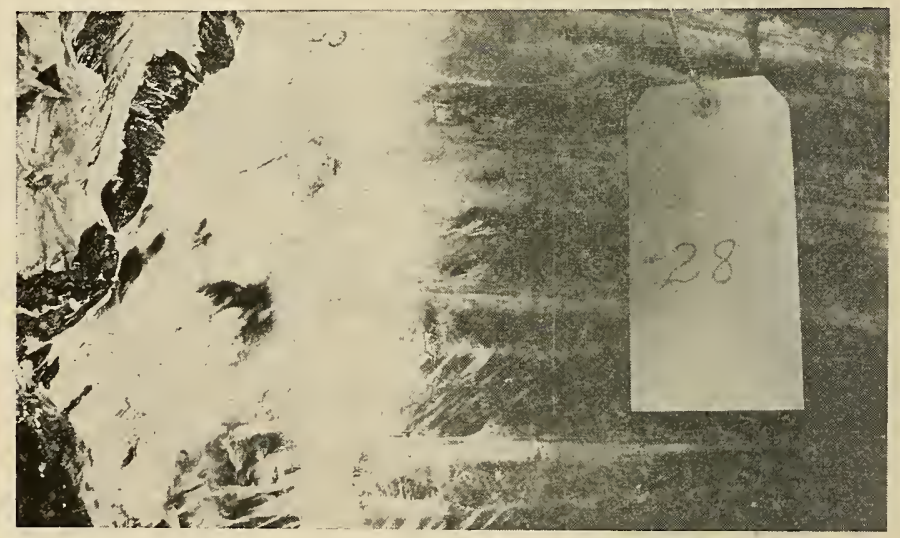

FIgUre 15.-Showing Enlargements Surrounding Junctions of Pils in Animal E 28

In general the analyses of such bones show that the ash and nonextractable organic matter are reduced while the moisture and extractable material are increased. The ash of the bones of the animals of Group IV, the group fed the ration low in both calcium and phosphorus, was more than 25 percent lower than that of the group fed the normal ration, while the ash of the animals in Groups II and III was lower than that of the normally-fed animals.

The bones of the low-mineral-fed animals were not calcified as well as those of the normal-fed group, and the breaking strength, with the exception of Group III, was considerably less than that of the animals fed the normal ration. 
normal-fed group. This was true but less pronounced of the animals in Group II and was least shown by those in Group III.

The animals in Groups I and III averaged highest in dressing percentage, which increased as the animals grew older. It was also observed that the animals in these two groups were in better condition as to flesh than those in Groups II and IV. This would indicate that the difference in the size of the interrial organs might be due largely to the difference in the mineral content of the ration.

No difference was noted in the general appearance of the organs of the several groups.

\section{GENERAL DISCUSSION OF RESULTS}

In bringing together the resilts of the experiment it is evident that the animals in Group I, the group which was fed a ration typical of those fed under practical conditions, obtained sufficient calcium and phosphorus for normal growth and development. They did not grow as well as might have been expected during the first year, but this probably was due to the poor start which they received and not to any deficiency in their ration. At the time of the last analyses the inorganic phosphorus in their blood was slightly low. This may have been due to the low phosphorus content of the ration, which during the last periods contained only 0.22 percent phosphorus and was providing only 1.9 gms. of phosphorus per day per hundredweight of the animal.

The optimum requirement for laioratory animals as found by McCollum and coworkers (1922) was 0.4146 percent phosphorus. This ration contained only a little more than one-half of this amount; in fact none of the rations fed after milk-feeding was discontinued contained as much phosphorus as this amount. It would hardly be expected, since the dairy animal is not as fast a growing animal as the rat, that it would require as much phosphorus in the ration as does the rat.

Armsby (1917) calculated that during the first year the normal animal retains $1.7 \mathrm{gms}$. of phosphorus daily per hundredweight of the animal. Since the animals in the normal group were receiving only a little more than is retained by normal animals, it can be seen that the animals in this group were being fed a ration dangerously close to the lower limits of phosphorus requirements.

Since this ration was being used as one typical of those being fed under practical conditions, the danger of underfeeding of phosphorus is evident. The animals in this group, however, were normal in weight and height at withers after the first year, were in good physical condition, and showed no abnormal physical characteristics throughout the experiment. Hence they must have received sufficient calcium and phosphorus.

The animals in Group II were fed a ration low in calcium but containing a little more phosphorus than was contained in the ration fed to the animals in the normal group. Any abnormal condition in 
the aninals of this group can be attributed to the low calcium content of the ration, since all animals were fed according to their requirements for digestible protein and digestible nutrients.

The ration fed during the first year contained 0.286 percent calcium and during the second year 0.249 percent. This during the first year was about 3.5 gins. and during the second year about 2.75 gms. per hundredweight of the animal. McCollum and coworkers (1922) found that the optimum requirement of calcium for growing rats was 0.641 percent, and Armsby (1917) calculated that the amount retained by normal cattle during the first year was $3.2 \mathrm{gms}$. of calcium per day per hundredweight of the animal. The ration fed contained in proportion considerably less than one-half of the optimum requirements for rats and during the first year just a little more than is retained by normally growing cattle. During the second year the ration contained a little less than is retained by normally growing cattle. It is evident then that these rations were low in their calcium content. The rations contained a little more phosphorus than did those fed to Group I and therefore they should not be lacking in phosphorus.

The animals in Group II did not grow so well, especially during the second year, as did those in Group I. This was shown both by weight and by height at withers. Neither were they in as good physical condition at any time, as shown by general appearance and dressing percentage. The blood, however, remained normal in its calcium and inorganic phosphorus content. Analyses showed that the green bones of the animals in this group were lower in ash and consequently lower in both calcium and phosphorus than were the bones of the normal group. The bones were slightly higher also in moisture and extractable material. This condition was true during the entire experiment, but it seemed to be improring toward the end of the trial. The circumstance would indicate that the animals as they grew older did not require as much calcium as they did when they were younger and making faster gains.

These animals averaged about $1 \frac{1}{2}$ months older at the time of the first signs of oestrum than those in Group I, and they were quite irregular thereafter. However, other than being in not quite as good condition and not growing quite as fast as Group I, Group II showed no abnormal physical characteristics. Their bones indicated, however, that they were being fed a ration too low in calcium for best development, but since they were liept for so long a time without very striking results, it would indicate that the ration was only slightly low in this element.

The animals in Group III during the second year were fed a ration containing only 0.131 percent of phosphorus. This provided about 1.43 gms. of phosphorus per day per hundredweight of the animals. The amount of calcitum in the ration was about the same as in the ration fed to the animals in the normal group. Any abnormal condition in the animals of this group can be attributed to the lack of phosphorus in the ration. It must be borne in mind, however, that 
the ration fed to the animals in this group was normal in its amount of phosphorus during most of the first two periods. Hence the effects of the ration fed could not be expected before this time, as it was then equal in both calcium and phosphorus to the ration fed to the normal group. Therefore only the difference noted during the latter part of the experiment is significant.

The animals in Group III grew almost as well as did those in Group I, both in height at withers and in weight during the first year, but during the last year they did not make quite as good gains. Their growth curves show them to have made much better gains than those in either Groups II or IV but this may have been due largely to the better start which they obtained because of the normal ration which they received during the first year. They were in better condition than those in Groups II and IV, as shown by dressing percentage and general appearance, but this again may have been due to the better start which they received. The first period of oestrum occurred at about the same time as that of the normal group, but that also would be as expected, since they were receiving a normal ration up to about that time.

When their ration was changed to a low-phosphorus ration, however, within a week the inorganic phosphorus in the blood had dropped to almost one-half what it had been previonsly and it remained there throughout the rest of the experiment.

Toward the end of the experiment one of the animals in this group became stiff in the hind legs, and the legs became slightly bent. The other animal became slightly sway-backed.

The amount of ash in the green bone also fell and continued low until the end of the experiment. This as usual was accompanied by a rise in the moisture and extractable material of the bones. The breaking strength of the bones remained normal in this group and the amount of marrow in the bones also was normal.

A study of these results indicates that the growing dairy animal must depend for her phosphorus supply largely upon her feed, especially when she is obtaining sufficient calcium in her feed. 'This is indicated first because of the almost inmediate decrease in the inorganic phosphorus of the blood when rations below the needs of the animal were fed; and second, whereas the total ash in the bones was decreased below normal, the shaft of the bone was not decreased in strength and there was no more marrow in it than in the normal bone.

While the ash content of the bones in the animals fed the lowcalcium ration was no less than it was in Group III, nevertheless the breaking strength of the bones was reduced, and the marrow increased in amount, notwithstanding the fact that the calcium content of the blood was not decreased. This would seem to indicate that, whereas the animal may draw upon the bone for its calcium in order to keep its blood supply normal, it cannot do so for phosphorus, especially if there is sufficient calcium in the ration. If this is true it might explain one of the reasons why the ratio of these elements should be kept within certain limits. 
The results also indicate that it is much easier to affect the phosphorus supply of the blood than the calcium supply in growing dairy animals. This is shown in a comparison of Groups II and III. The bones of both of these groups were affected in comparison to about the same degree, but whereas the blood of Group IV was lowered materially in phosphorus, that of Group III was maintained at normal in calcium.

Group IV was fed a ration low in calcium and after the first two periods low also in phosphorus. During the first two periods the ration compared with that fed to Group II, and the results were very similar. They grew at about the same rate as indicated by weight and height at withers. The results of the analyses of the bones also were very similar.

At about the end of the second period the ration fed was low also in phosphorus, containing only about 0.133 percent of that mineral. The inorganic phosphorus content of the blood immediately dropped to about one-half that of normal. The calcium content of the blood remained normal throughout the entire experiment, however. This group showed more serious symptoms than any of the others. The composition of the bones was greatly affected. The ash was lowered to less than three-fourths that of normal bones and contained much more moisture and extractable material than normal bones. The calcium and phosphorus were correspondingly lowered. The breaking strength of the bones was not much over one-half that of normal bones. The animals also took on abnormal appearance toward the end of the experiment. They became sway-backed and one individual became slightly bent in the legs.

This ration was very similar to Ration II in its calcium content (slightly higher) and to Ration III in its phosphorus content (slightly higher), but the effects were much worse than in either of these groups. This would show that both calcium and phosphorus were too low in these rations for the normal well-being of the animals. 


\section{SUMMARY AND CONCLUSIONS}

Four groups of growing dairy animals were fed in such a way that all were receiving approximately the same amount of digestible crude protein and total digestible nutrients. Group I was fed a supposedly normal ration in so far as its content of phosphorus and calcium was concerned. Group II was fed a ration low in calcium but with sufficient phosphorus. Group III was fed a ration low in phosphorus but with sufficient calcium, and Group IV was fed a ration low in both calcium and phosphorus. No effort was made to supply the anti-rachitic vitamin, and the animals were kept in a building where the sunlight came in only through common window glass.

The effects of the ration were studied by weighing and measuring the animals at weekly intervals, by analyzing the blood for inorganic phosphorus and calcium, and by analyzing the bones for moisture, extractable material, ash, and the ash for calcium and phosphorus. Data were also taken as to condition of animal, abnormalities, time of showing oestrum, and any other factors which could be attributed to the ration.

Under the conditions of the experiment as outlired, the following conclusions were reached:

Growing dairy animals fed rations low in calcium ( 0.286 percent or less) or low in both calcium ( 0.331 percent or less) and phosphorus (0.298 percent or less), but otherwise ample in nutritive value, grow nearly as well as normal-fed animals for some time, but over a period of two years do not make as good gains as measured by weight and height at withers. Animals fed a ration low in phosphorus $(0.131$ percent) during the second year continued to grow almost as well as did normal-fed animals, even though the inorganic phosphorus content of their blood was much below normal.

The inorganic phosphorus in the blood of growing dairy animals can be more easily reduced than can the calcium content by feeding rations low in these minerals.

Rations containing less than 0.20 percent of phosphorus will decrease the amount of inorganic phosphorus in the blood.

Rations containing as little as 0.25 percent of calcium will not affect the calcium content of the blood.

Growing dairy animals when fed rations low in phosphorus cannot draw sufficient phosphorus from their bones to maintain the normal supply of inorganic phosphorus in the blood.

Rations which contain less than 0.35 percent of calcium or less than 0.20 percent of phosphorus give rise to a bone which is low in ash and consequently low in calcium and phosphorus but high in moisture and extractable material.

The ash of bones contains approximately the same percentage of calcium and phosphorus regardless of the rations fed. 
Either the ribs or femurs and humeri can be used for analysis with the same general results.

Rations which are fed under practical conditions may be dangerously near the lower limits of phosphorus requirements.

The analyses of the bones of the animals in the normal group give figures which are fairly representative of the composition of the bones of normal dairy animals at various ages.

\section{LITERATURE CITED}

Afissbr, H P.

1917. THE Nutriltox of Farmi ANimals. $747 \mathrm{p}$. New York.

Arox, H. and SEbJUER, R.

1908. UNTERSUCHUAGEN UEBER DIE BEDEUTTNG DER KAIKSALZE FUER DEN WACHSENDEN ORGANISMUS. Biochem. Zeit, $s: 1$.

Astox. B. C.

1905. BUsin op taxganda disease. 13th Amn. Rept., N. Zeal. Dept. Agr.: S1.

Bel.t, R. D., and Dorss, E. A.

1920. RAPID COIORIMETRIC MFTHOD FOR THE DETERMINATION OF PHOSPHORUS IN URINE AND BLOOD. Jour. Biol. Chem. 44:55.

BethKe, R. M., STEexbock, H., and Nessor, M. T.

1923. FAT SOLLBLE VITAMINS-XV. CALCIT M AND PHOSPIIORUS RELATIONS TO GROWTII AND COMPOSITION OF BLOOD AND DONE WITH VAFYING VITAMIN INTAKE. Jour. Biol. Chem. 5S:71.

BITTING, A. W.

1594. BIG HEAD (Osteoporosis). Fla. Agr. Expt. Sta. Bul. 26, p. 53-63.

BoHsledt, G. 1926. mineral and vitamia requirements of Pigs. Ohio Agr. Expt. Sta. Bul. 395 .

- Betilke, R. M., Edgington, B. II., and Robisox, T. L. 1927. JINERALS AND VITAMINS IN RITIONS OI PIGS. Ohio Expt. Sta. bimonthly Bul. 12:t57.

Briggs, A. P.

1922. A MODIFICATION OF THE BeLL-DOISY PHOSPIATE METHOD. Jour. Biol. Chem. $53: 13$.

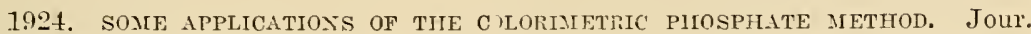
Biol. Chem. $59: 255$.

Ciiossat, C.

1S42. xote str le systeme osseux. Compt. Rend. Acad. des Sci. 14: 451.

Cited in Ohio Agr. Fxpt. Sta. Tech. Bul. 5, p. 384.

Dais, H. P., Mastrovsky, B., Netexs, W. B., Woonty ard, E. G.. Hexdrickson, J. W., and Frandsex, J. B.

1922. Gliow'Th studies of Daipy heifeis. Neb. Agr. Expt. Sta. Bul. 181. 
ECKILS, C. H.

1915. THE RATJON AND AGE OF CALVING AS FACTORS INFLUENCING THE GROWTH AND Dairy Qualities of Cows. Mo. Agr. Expt. Sta. Bul. 135.

, and SWETT, W. W.

1918. SOME FACTORS INELUENCING TIIE RATE OF GROWTH AND SIZE OF DAIRY inejfers at Maturity. Mo. Agr. Expt. Sta. Res. Bul. 31.

1920. The Normal Growth of DaIRy Cattle. Mo. Agr. Expt. Sta. Res. Bul. 36.

- — Becker, R. B., and PALMER, L. S.

1926. A mineral deficiency in que rations of cattle. Minn. Agr. Expt. Sta. Bul. 229.

Forbes, E. B., Befgie, F. M., and Mensciing, J. E.

1913. Mineral AND ORganid ANAlyses of Foods. Ohio Agr. Expt. Sta. Bul. 255, p. $225-231$.

- - Fritz, C. M., MorgaN, L. E., and RHes, S. N.

1916. THE MINERAL imETABOLISM OF THE MILCH COW. FIRST PAPER. Ohio Agr. Expt. Sta. Bul. 295.

1917. tile mineral metabolism of the milch cow. II. Ohio Agr. Expt. Sta. BuI. 308.

- - Halverson, J. O., and Morgan, L. F.

1918. THe Mineral Metabolism of tile Milch cow. III. Ohio Agr. Expt. Sta. Bul. 330.

- Hunt, C. H., Schulz, J. A., Winter, A. R., and Remler, R. F. 1922. The Minera metabolism of tite MiLCh cow. Ohio Agr. Fixpt. Sta. Bul. 363.

- - Scilulz, J. A., Hunt, C. H., Winter, A. R., and Remler, R. F.

1922a. Mineral Metabolism of the Milk cow. Jour. Diol. Chem. 52:281.

Forster, J. M.

1873. VERSUCHE UEBER DIE BEDEUTUNG DER ASCHENBESTANDTHEILE IN DER NAHRUNG. Zeit. Biol. 9:297.

GOIIREN, F. VON.

1861. UEBER EINE BEIGABE VON KNOSHENERDE ZUM FUTTER DER TIIIERE NEBST FINEM PHYSIOLOGISCII-CHEMISCILEN VERSUCH UEBER DEREN VERDAULICHKEIT. Landw. Vers. Sta. 3:161-171.

Guldickson, T. W., and EckLws, C. H.

1927. THF RELATION OF SUNLJGITT TO THE GROWTH AND DIEVLOPMENT OF CALves. Jour. Dairy Sci. 10:\$7.

HaAg, J. R., and PALMer, L. S.

1928. TIIE EFFECT OF PARIATIONS IN THE PROPORTIONS OF CALCIUM, MAGNESICM, AND PHOSPHORUS CONTAINED IN THE DIET. Jour. Biol. Chem. 74:367.

Halverson, J. O., MoHijer, H. K., and Gorgein, O.

19.17. TJE CALCIUM CONTENT OF TIIE BLOOD SERUM IN CERTAIN PATHOLOGICAL conditions. Jour. Biol. Chem. 32:171.

- -

1924. THE CALCIUM REQUIREMENT OF ANIMALS IN REIAATION TO THE CALCIUM content of Feeds. N. Car. Dept. Agr. Bul. June, 1924, p. 430-431.

HAMMETT, F. S.

1925. A BIOCHEMICAL STUDY OF BONE GROWTH: I. CIHANGES IN TIIE $\Lambda$ SH, ORgaNic MatTer, AND WATer DURING Growth. Jour. Biol. Chem. 64:409.

1925a. A BIOCHEMICAL STUDY OF BONE GROWTH: II. CHANGES IN TIIE CALCIUM, MAGNeSIUM, AND PHOSPHORUS OF BONE DURING GROWTH. Jour. Biol. Chem. $64: 685$. 
19251. A BIOCILMICAL STUDY OF BONE GROWTIY: MI. CIIANGES IN THE CONPOSITION of TIE ASII DURING GRowily. Jour. Biol. Chem. 64:603.

HANT, E. B., MLCOLLdir, E. V., and Fuliter, J. G.

1909. THIF ROLE OR INORGANIC PIIOSPIIORUS IN TIIT NUTRITION OF ANIMALS. Wis. Agr. Expt. Sta. Res. Bul. 1.

- - HALPIN, J. G., and Steeniock, II.

1920. USE OF STNIIETIC DIETS IN TIE GROW'II OF BABX CHICKS. Jour. Biol. Chem. 43.

, Steeneock, H., and Hoppert, C. A.

1921. I. TIIE COMPARATIVE INFLULNCE OT GREEN AND DRIED PLANT TISSUE, CAPBAGE, ORANGE JUICE, AND COD-LIVER OIL ON CALCIUM ASSIMILATTON. Jour. Biol. Chem. $48: 33$.

一, - - - Pethe, R. M., and Humpifrex, G. C.

1922. III. THE COMPARATIVE EFFICIENCX OF TIMOTHX IIAY, ILFALFA HAY, AND tialothy PLUS CAICIUM PHOSPHATE IN MAINTAINING CALCIUM AND pHosphorus equilibrium IN Milking cows. Jour. Biol. Chem. 54:75.

$-\longrightarrow,--\cdots,-$, and Humpirey, G. C.

1023. DIETARY FACTORS INEIUTNCING CAICIUM ASSIMILATION: TV. TIIE COMPARATIVE EFFICIENCY OF MIXED GREEN GRASSES AND TIIE SAME MIXTURE PIAS STEARED BONEMEAL IN NAINTAINING CALCIUM AND PHOSPHORUS EQUILIPRIUM IN MILKING Cows. Jour. Biol. Chem. 58:43.

1923a. II. THE COMPARATIVE EFFICLENCY OF DRY AND GREEN ALFALFA IN MAINTAINING CAICIUZI AND PHOSPIIORUS EQUIIIBRIUA IN MILEING COWS. Jour. Biol. Chem. 53:21.

- - -

1924. DIETARY F.ACTORS AFFECTING CALCIUM ASSIMILATION: V. THE EFFFCT OF LIGHT UPON CALCIUM AND PHOSPHORUS EQUILIBRIUM IN MATLRE LACTATing Anialas. Jour. Biol. Chem. 62:117.

- - - Humphrex, G. C., and Hulce, R. S.

1924. NETV OBSEFVATIONS AND A NEW INTERPRETATION OF OLD OBSERVATIONS ox tile nutritive value of the Wheat Plant. Jour. Biol. Chem. 62:315.

, Beacir, B. A., Delwicie, E. J., and Billey, E. G.

1927. PJiOSPItORUS DEFICIENCY AND A DAIRY CATTLE DISEASE. Wis. Agr.

Expt. Sta. Bul. 399.

Henry, W. A., and Morrison, F. B.

1923. FeEdS AND feEding. Ed. 1S. 770 p. Madison.

Hess, A. F., P.iprfiniemine, A. M., and Weinstock, M.

1922. A STUDY OF LIGHT WAVES IN RELATION TO THEIR PROTEC'TIVE ACTION IN Rickets. Soe. Exp. Biol. and Med. Proc. 20:14-16.

Jorndx, W. H., Hart, E. B., and Patten, A. J.

1906. A STUDY OF TIIE METABOLISN AND PHYSIOLOGICAL EFFECT OF CERTAIN PIIOSPHORUS COMPOUNDS WITi MLK COWs. N. Y. Agr. Expt. Sta. Tech. Bul. 1.

KELLNER, O.

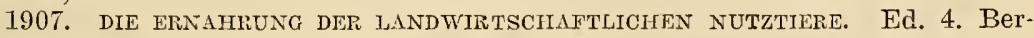

lin. Cited in Ohio Expt. Sta. Tech. Bul. 5, p. 421.

Kruger, J. H., and BECHDEL, S. I.

192S. STUDIES IN THE NORMAT DFPOSITIONS OF MINERALS IN THE BONES OF DAIRT CALVES. Jour. Dairy Sci. 11:24.

Marce, J.

1925. NUtritive valut of PHosphorus in CAttle FeediNg. Intern. Rev.

Sci. Practice Agr. 3:58-64. Cited in Chem. Abst. 19:2690. 
Maynard, L. A., Goldberg, S. A., and Miller, R. C. 1925. A STUDY OF TIIE DIETARY RELATIONSIIIP AND THE PATHOLOGY OF STIFFNESS IN STINE. Cornell Memoir, 86.

Meigs, E. B., Blathifrwick, N. R., and Cary, C. A. 1919. CONTRIBUTIONS TO THE PHYSIOLOGY OF PHOSPIORUS AND CALCIUM metabolisis as relazed to milk Secretion. Jour. Biol. Chem. 37:1.

- _ and WoonWARD, T. E.

1921. INFIUENCE OF CALCIUM AND PHOSPHORUS IN THE FEED ON THE MILK YIELD OF DAIRY COWS. Jour. Dairy Sci. 4:185.

Mellanby, E.

1919. AN EXPERIMENTAL INVESTIGATION ON RICJETS. Lancet: March 15, p. 407.

McCanduish, A. C.

1923. STUDIES IN THE GROWTIT AND NUTRITION OF DAIRY CALTES: VI. TFIE ADDITION OF HAY AND GRAIN TO A MILK RATION FOR CALVES. Jour. Dairy Sci. $6: 347-372$.

McCollum, E. V., Simmonds, N., Shipley, P. G., and Park, E. A.

1921. THE EFFECTS ON GROWING RATS OF DIETS DEFICIENT IN CALCITM. Amer. Jour. Hyg. 1:492.

1921a. VII. THE PRODUCTION OF RICKETS BY DIETS IOW IN PHOSPHORUS AND FAT-Soluble A. Jour. Biol. Chem. 47:507.

- - - -

1922. AN EXPERIMFNTAL DEMONSTRATION ON THE EXISTENCE OF A VITAMIN WHiCH PROMOTES CALCIUM DEPOSITION. Jour. Biol. Chem. 53:293.

- - - - Kinney, M., Shipley, P. G., and Park, E. A.

1922a. STUDIES ON EXPERIMENTAL RICKETS: XVII. THE EFFECTS OF DIETS DEFICIENT IN CALCIUM AND IN FA'T-SOLUBLE A IN MODIFYING THE HISTOLOGICAL StRUCTURe OF THE BONES. Amer. Jour. Hyg. 2:97.

1927. THE NEWER KNOWLEDGE OF NUTRITION. Ed. 3. 655 p., illus. New York.

Moulton, C. R., Trowbridge, P. F., and HaigiI, L. D.

1918. STUDIES IN ANIMAL NUTRITION: I. CHLANGES IN FORM AND WEIGHT ON DIFFErent PI ANES of NUtrition. Mo. Agr. Expt. Sta. Res. Bul. 43.

Murphy, E. W.

1917. TREATMENT OF PASTURES. PREVENTION OF RICKETS, CRIPPLES, AND paralysis. Jour. Dept. Agr. Victoria 15:449-456. Cited in Minn. Agr. Expt. Sta. Bul. 229.

Nessler, J.

1873. II. UNTERSUCHUNGEN DER KNOCHEN VON KNOCHENBRUCHIGKEITEM RINDVIEH. Landw. Vers. Sta. 16:187.

Osporne, T. B., and Inendel, L. B.

1918. the inorganic elements in nutrition. Jour. Biol. Chem. 34:131.

Pelirson, L.

1898. abnormal (Depraved) appetite in cattle. Pa. Dept. Agr. Bul. 34: 131-132.

Reed, O. E., Fitch, J. B., and CAVE, H. W.

1924. THE RELATION OF FEEDING AND ACX OF CALVING TO THE DEVELOPMENT of DAIRY HeIFers. Kans. Agr. Exp. Sta. Bul. 233.

, and HufFMan, C. F.

1925. THE IMPORTANCE OF WELL-CURED HAY IN THE RATION OF DAIRY CATTLE. Holstein-Friesian World, 23:8. 
192S. PIIOSPHORU'S FOR DAIRY CATTLE. Hoard's Dairyman 73:618.

Rose, A. R.

1912. A STUDY OF TIEE METABOLISM AND PIIYSIOLOGICAL EFFECTS OF CERTAIN phospilorits compounds with Milk cows. N. Y. Agr. Expt. Sta. Tech. Bul. 20.

Salimon, W. D., and Eaton, W. H.

1925. EFFECT OF BONEMEAL ON GROWTIL OF DAIRY IIEIFERS. Jour. Dairy Sei. S:312-917.

ScIImit, H.

1924. FIELD AND LABORATORY NOTES ON A FATAL DISEASE OF CATTLE OCCURRing on the codstal plates of texas (LoIN disease). Texas Agr. Expt. Sta. Bul. 319.

Simerman, H. C., and Pappenheimer, A. M.

1921. A DIETETIC PIODUCTION OF RICKETS IN RATS AND ITS PREVENTION BY INorgaxic SAlts. Proc. Soc. Exp. Biol. and Med. 18:193.

Steenbock, H., Hart, E. B., Jones, J. H., and Black, A.

1923. FAT-SOLUBLE VITAMINES: XIV. THE INORGANIC PIIOSPIIORUS AND CALCIUM OF THE BLOOD USED AS CRITERLA IN TIIE DEMONSTRATION OF THE EXISTeNCE of a specific antirachitic vitamix. Jour. Biol. Chem. 58:59.

THeiler, A.

1920. The CaUSe AND PRevention of LAMziekte. Jour. Dept. Agr. Union of S. Afr. 1:221-247.

- - Greex, H. H., and Du ToIT, P. J.

1924. PHOSPHORUS IN THE LIVESTOCK INDUSTRy. Jour. Dept. Agr.. Union of S. Afr. 8:460-504.

'Trowbridge, P. F., Moulton, C. R., and Haigh, L. D.

1915. TIIE MAINTENANCE REQUIREMENT OF CATTLE AS INFLCENCED BY CONDITION, PLANE OF NUTRITION, AGE, SEASON, TIMF. ON MAINTENANCE, TYPE, AND Size of Aximal. Mo. Agr. Expt. Sta. Res. Bul. 18.

191S. EEFECT OF LIMITED FOOD SUPPLY ON THE GROWTII OF YOUNG BEEF Animals. Mo. Agr. Expt. Sta. Res. Bul. 2 S.

TuFF, P.

1924. osteomalacia AND its OCCURREnce IN CATtLe IN NORWAY. Proc. World's Dairy Congress 2:1494.

VoIT, E.

18S0. UEBER DIE BEDEUTUNG DES KALKES FUER DEN THIERISCHEN ORGANISMUS. Zeit. Biol. 16:55.

WEISKE, H.

1872. UEBER DEN FINFLUSS VON KALK ODER PHOSPIIORSAEURFARME NAHRUNG AUF DIE zUSAMMENSETzUNG DER KNOCHeN. Landw. Vers. Sta. 15:152.

1873. LN'TERSUCHUNGEN UEBER DIE ZUSAMMENSETZUNG DER KOCHEN BEI KALK ODER PHOSPHORSAEUREN NAHRUNG. Zeitschr. Biol. 9:541-547.

WELCH, $\mathbf{H}$.

1924. Bone-CheWing By CAttle. Montana Ágr. Expt. Sta. Circ. 122. 


\section{TABLE OF CONTENTS}

PAGE

Introduction

Review of Literature

Methods Employed in the Experiment

Description of Animals Fed

Housing and Care of the Animals _.......... 7

Exercise _.......... 8

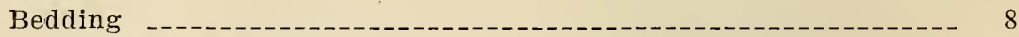

Weighing and Measuring _..._.

Breeding -

Salting -

Water _...-........ 8

Methods of Feeding

Early Feeding _._._._._. 9

Analysis of Rations _-_.

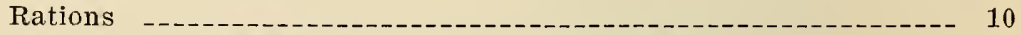

Calcium and Phosphorus Content of the Ration _............ 11

Discussion of the Rations Fed

Amount of Phosphorus and CaIcium Fed

Ratio of Calcium and Phosphorus

Factor Which Assists in the Assimilation of Calcium and

Phosphorus

Results of the Experiment

Effects of Rations on Growth and Development of the Animals

Growth

Discussion of Results

Physical Abnormalities

Abnormal Cravings _.

Drinking Habits

Effect of Rations upon the Oestrum of the Animals

Discussion of Results

Effect of Rations upon the Calcium and Inorganic Phosphorus Content of the Blood - 27

Analyses of Blood _-

Calcium -

Phosphorus - .

Study of Individuals

Discussion of Results 30

Effect of the Rations upon the Bones of the Animals... 33

Effect of Composition

Sampling the Bones

Method of Analysis

Analysis of Ribs _._.

Analysis of Femur and Humerus

Discussion of Results _._.

Effect on Appearance

Effect on Breaking Strength

Summary _.

Effect of Rations upon Internal Organs and Dressing Percentage...- 45

General Discussion of Results

Summary and Conclusions

Literature Cited _...... 51 


